\title{
Typology of extreme flood event leads to differential impacts on soil functioning
}

Rafael Sanchez-Rodriguez, Antonio; Hill, Paul W.; Chadwick, David R.; Jones, Davey L.

\section{Soil Biology and Biochemistry}

DOI:

10.1016/j.soilbio.2018.11.019

Published: 01/02/2019

Cyswllt i'r cyhoeddiad / Link to publication

Dyfyniad o'r fersiwn a gyhoeddwyd / Citation for published version (APA):

Rafael Sanchez-Rodriguez, A., Hill, P. W., Chadwick, D. R., \& Jones, D. L. (2019). Typology of extreme flood event leads to differential impacts on soil functioning. Soil Biology and Biochemistry, 129, 153-168. https://doi.org/10.1016/j.soilbio.2018.11.019

\footnotetext{
Hawliau Cyffredinol / General rights

Copyright and moral rights for the publications made accessible in the public portal are retained by the authors and/or other copyright owners and it is a condition of accessing publications that users recognise and abide by the legal requirements associated with these rights.

- Users may download and print one copy of any publication from the public portal for the purpose of private study or research.

- You may not further distribute the material or use it for any profit-making activity or commercial gain

- You may freely distribute the URL identifying the publication in the public portal ?
}

Take down policy

If you believe that this document breaches copyright please contact us providing details, and we will remove access to the work immediately and investigate your claim. 


\section{Typology of extreme flood event leads to differential impacts on soil functioning}

2 Antonio Rafael Sánchez-Rodríguez ${ }^{\mathrm{a}, \mathrm{b}, *}$, Paul W. Hill ${ }^{\mathrm{a}}$, David R. Chadwick ${ }^{\mathrm{a}}$, Davey L. Jones ${ }^{\mathrm{a}, \mathrm{c}}$

3 a School of Environment, Natural Resources and Geography, Environment Centre Wales,

$4 \quad$ Bangor University, Gwynedd LL57 2UW, UK

5 b Departamento de Agronomía, Universidad de Córdoba, ETSIAM, Córdoba, Andalucía $6 \quad$ 14071, Spain

$7 \quad{ }^{\mathrm{c}}$ UWA School of Agriculture and Environment, University of Western Australia, Crawley, WA 8 6009, Australia

*Corresponding author. Tel.: +44 1248 383052; fax: +44 1248354997.

E-mail address: antonio.sanchez@uco.es (A.R. Sánchez-Rodríguez).

\section{ABSTRACT}

Soils around the world are being exposed to weather events which are unprecedented in recent history. To maintain the delivery of soil-related ecosystem services and to promote greater soil resilience it is essential to understand how plant-soil systems respond to these extreme events. In this study we replicated a recent period of extreme rainfall and prolonged spring flooding in a temperate grassland which had no previous history of flooding. Intact soil mescosms (Eutric Cambisol) $1 \mathrm{~kg}$ weight were subjected to a simulated long-term spring flood $\left(15^{\circ} \mathrm{C}, 2\right.$ months) and maintained in the light with above ground indigenous vegetation (Lolium perenne L.) or dark with and without indigenous vegetation to simulate different flood typologies. In comparison to a no-flood control treatment, nutrient cycling, water quality, air quality (greenhouse gas emissions), habitat provision and biological population regulation shifts were evaluated. Flooding induced a rapid release of nutrients into the soil solution and overlying floodwater, resulting in potential nutrient losses up to $15 \mathrm{mg}$ Fe, $16 \mathrm{mg}$ $\mathrm{NH}_{4}{ }^{+}, 360 \mathrm{mg}$ DOC and $28 \mathrm{mg}$ DON, per mesocosm. The presence of plants increased the 
rate of nutrient release (especially $\mathrm{P}$ ), with the effects magnified when light transmission through the floodwater was restricted (1.3 $\mathrm{mg} \mathrm{P}$ vs $0.2 \mathrm{mg}$ P, per mesocosm). Flooding induced a rapid decline in redox potential and subsequent production of $\mathrm{CH}_{4}$, especially in the darkened treatments (10 and between 11-16 times higher than the control, without and with light restrictions, respectively). Upon removal of the floodwater, the accumulated $\mathrm{NH}_{4}^{+}$was nitrified leading to a shift in greenhouse gas emissions, from $\mathrm{CH}_{4}$ to $\mathrm{N}_{2} \mathrm{O}$ emissions. $\mathrm{N}_{2} \mathrm{O}$ was only significantly produced in the mesocosms kept under light restrictions (13 times higher than in other two treatments). Flooding eliminated earthworms, reduced grass production after soil recovery (from $28 \mathrm{~g}$ for control mesocosms to $11 \mathrm{~g}$ and $<1 \mathrm{~g}$ for flooded mesocosms without and with light restrictions, respectively). Soil microbial biomass was also reduced (up to a $22-27 \%$ of the total PLFAs) and flooding induced shifts in microbial community structure, particularly a loss of soil fungi. The soil fungi content quickly recovered (4 weeks) when light was not restricted during the flood period, however, no such recovery was seen in the darkened treatments. Overall, we conclude that extreme flood events cause rapid and profound changes in soil function. Both the impact of the flooding and the time to recover is exacerbated when light is restricted (e.g. in sediment laden floodwater). In addition, our results suggest that the presence of flood-resilient plants can mitigate against some of the negative impacts of flooding on soil functioning.

Keywords: Climate change, nitrate, PLFA profiling, tipping point, waterlogging tolerance, ${ }^{33} \mathrm{P}$ 


\section{Introduction}

Against a backdrop of progressive climate change, there is increasing evidence that many ecosystems are also experiencing more extremes in weather (e.g. heat, droughts, floods and ground level ozone; Easterling et al., 2000). Within Western Europe, recent quasi-stochastic extremes in air temperature and changes in the periodicity and intensity of rainfall have been directly linked to climate change (Allan, 2011; Pall et al., 2011; Jones et al., 2012). To a large extent this appears to be due to behavioural changes in the North Atlantic oscillation weather system which is influenced by the polar vortex and Pacific jet stream (Murphy et al., 2009). Alterations in this weather system have now been linked to numerous unprecedented storms and long-term flooding events within the UK (Met Office, 2014). Examples of these include those seen in the summer of 2012 and in the winter of 2013-2014 when large areas within the England and Wales remained flooded for 10-12 weeks, in some cases under several metres of floodwater (McEwen et al., 2014). Although some of these areas clearly lie within flood plains which have a long history of inundation, importantly, other areas with no previous documented history (>150 years) of flooding were also affected (Clout, 2014; Thorne, 2014). These agroecosystems were severely impacted by the long-term flooding, typically resulting in complete crop failure, loss of soil functions and in some cases a complete loss of topsoil due to water erosion (Natural England, 2014). After the floodwater receded, it was also apparent that there was a lack of appropriate interventions to reverse the negative impacts on soil functioning as the impacts of extreme flooding were poorly understood. There is therefore a clear need to understand the impact of extreme precipitation events on the soils with no previous history of flooding.

Depending on the typology of the flood event, i.e. duration, depth, origin of the water (Sánchez-Rodríguez et al., 2018), and the soil/vegetation combination, prolonged inundation is expected to impact upon soil functions to different extents. Bünemann et al. (2018) has recently reviewed the multiple aspects and definitions of soil quality. In this manuscript, we 
define soil quality as "the capacity of a soil to function within ecosystem and land-use boundaries to sustain biological productivity, maintain environmental quality, and promote plant and animal health" (Doran and Parkin, 1994, 1996). While short term flooding ( $<7 \mathrm{~d})$ may have limited impact on soil functions, extreme flood events ( $>2$ months) may have major consequences on the delivery of a range of ecosystem services both during the flood itself and during the recovery phase (Niu et al., 2014), such as biomass production, biodiversity and water quality and supply. These soil-based ecosystem services are associated with soil functions, including habitat provision for roots and soil organisms, element cycling, decomposition, maintenance of soil structure, regulation of biological populations, water cycling and organic matter cycling (Bünemann et al., 2018).

After a few weeks of flooding, anaerobic conditions prevail in flooded grassland soils, facilitating the solubilisation of reduced elements (e.g. Fe, Mn; Schalenghe et al., 2007) and alterations in nutrient $(\mathrm{P}, \mathrm{Fe}, \mathrm{N}, \mathrm{C})$ cycles, including the release of soluble $\mathrm{C}$ and $\mathrm{N}$ (Jones et al., 2009) and promoting the loss of nutrients (via leaching or to the overlying water column). In addition, light ingress can be reduced preventing photosynthesis and inducing plant senescence (Mommer et al., 2005a; Shaw et al., 2013) depending upon the nature of the floodwater (particles suspended within the water column and deposited onto the foliage surface). Under these anaerobic conditions certain greenhouse gas (GHG) emissions could be stimulated; $\mathrm{CH}_{4}$ production and $\mathrm{N}_{2} \mathrm{O}$ emissions related to denitrification (transformation of $\mathrm{NO}_{3}{ }^{-}$to $\mathrm{N}_{2} \mathrm{O} / \mathrm{N}_{2}$ mediated by soil bacteria) are anticipated (Hou et al., 2000), but $\mathrm{N}_{2} \mathrm{O}$ production due to nitrification (transformation of $\mathrm{NH}_{4}{ }^{+}$to $\mathrm{NO}_{3}{ }^{-}$mediated by soil bacteria) will be reduced as it is an aerobic process (Norton, 2008). These conditions facilitate the decomposition of organic matter derived from the senescing plant material and obligateaerobic components of the microbial community. Soil microbial communities and some soil microorganisms, e.g. fungi, could be negatively affected if the inundation is prolonged, while other taxonomic groups, e.g. Gram+ bacteria, may prove more resistant (Ferré et al., 2012). 
Phospholipid-derived fatty acids (PLFAs) as bioindicators of different taxonomic groups have

been traditionally used to assess these alterations in microbial communities of flooded soils (Bossio and Scow, 1998). Finally, eutrophication of water bodies and a decline in soil functionality and associated ecosystem services are expected after a prolonged flooding event (Scalenghe et al., 2012; Brun and Barros, 2013; Shaw et al., 2013).

Until now, flooding experiments have largely focused on the options to mitigate flood risk. They have usually been short term laboratory studies with disturbed soil, without vegetation and non-extreme flooding, as reviewed by Brun and Baros (2013) and Shaw et al. (2013). There is a lack of information about the magnitude of long-term flooding and its effects on agricultural grasslands. Therefore, more realistic mesocosm experiments are needed to better understand soil ecosystem responses during and after extreme flood events, and to help develop strategies to minimize the effects of these events on agricultural land.

The main aim of this study was to evaluate the impact of different types of extreme flood event ( 9 weeks) on soil functioning within intact soil mesocosms with and without indigenous vegetation to reflect different possibilities that can occur in nature, in comparison with nonflooded mesocosms. Four different flood typologies were designed to separate the influence of above-ground and below-ground processes (i.e. flooded soil cores with indigenous vegetation versus flooded soil cores without indigenous vegetation) and to simulate the presence or absence of turbid floodwater (i.e. dark versus light conditions). Specifically, we addressed: (i) alterations in element cycling and water quality (Fe, P, N, C) during the extreme flood event ( 9 weeks) and 5 weeks of soil recovery, air quality (GHG emissions), habitat provision and biological population regulation during 5 weeks after the floodwater was removed (changes in soil microbial community structure, number of earthworms); and (ii) the relation between the cause of these alterations (flood typology), soil parameters and GHG emissions. We hypothesised that (i) flood types in which the availability of light is restricted will result in a greater loss of soil functionality due to negative feedbacks caused by 

light is not restricted and will be key to maintaining soil function during and after flooding.

the death of the vegetation, and (ii) a part of the indigenous vegetation will survive when the

\section{Materials and methods}

\subsection{Soil sampling and soil properties}

Sixteen intact soil samples were collected directly from the surface Ah horizon (0-10 $\mathrm{cm}$ ) of a sheep-grazed, Lolium perenne L. dominated, low intensity grassland, located in Abergwyngregyn, Gwynedd, North Wales $\left(53^{\circ} 14^{\prime} 21^{\prime \prime} \mathrm{N}, 4^{\circ} 00^{\prime} 57^{\prime \prime} \mathrm{W}\right)$ in October 2014 . The soil samples, which consisted of $100 \mathrm{~cm}^{3}$ blocks, were removed intact with associated vegetation (sward height ca. $4 \mathrm{~cm}$ ). The soil is classified as a sandy clay loam textured Eutric Cambisol with fine crumb structure as detailed in Palomo et al. (2006) and summarized in

Table S1. The soil receives an annual fertiliser dose of $100 \mathrm{~kg} \mathrm{~N} \mathrm{ha}^{-1}, 20 \mathrm{~kg} \mathrm{~K} \mathrm{ha}^{-1}$ and $20 \mathrm{~kg}$ $\mathrm{P} \mathrm{ha}^{-1}$.

Soil electrical conductivity (EC) and $\mathrm{pH}$ were determined in 1:1 (v/v) soil: distilled $\mathrm{H}_{2} \mathrm{O}$ extracts (Smith and Doran, 1996). Calcium carbonate $\left(\mathrm{CaCO}_{3}\right)$ was determined by the Van Slyke manometric method (Nelson, 1982). Exchangeable cations (Na, K, Ca, Mg and Al) were extracted by shaking $\left(1 \mathrm{~h}, 20^{\circ} \mathrm{C}\right)$ using a $1: 10(\mathrm{w} / \mathrm{v})$ soil:0.5 $\mathrm{M} \mathrm{BaCl}_{2}$ extract with subsequent cation analysis using a Series 720 ICP-OES (Agilent Technologies Inc., Santa Clara, CA). Available P was quantified in a 1:5 (w/v) soil:0.5 M acetic acid extract $(1 \mathrm{~h}, 200$ rev $\min ^{-1}$ ) with subsequent $\mathrm{P}$ analysis by the molybdate blue method of Murphy and Riley (1962). A CHN-2000 analyser (Leco Corp., St Joseph, MI) was used to determine total organic carbon (C) and nitrogen (N) in soil. $\mathrm{NO}_{3}{ }^{-}$and $\mathrm{NH}_{4}{ }^{+}$in soil solution were extracted according to Giesler and Lundström (1993) and determined with a Skalar San $^{+}$segmented flow analyser (Skalar UK Ltd, York, UK).

\subsection{Experimental design and treatments}


153 placed at the bottom of transparent $110 \times 80 \times 270 \mathrm{~mm}(1 \times \mathrm{w} \times \mathrm{h})$ polypropylene containers. The top of the containers were left open to facilitate gas exchange. No drainage holes were placed in the base. The containers were transferred to a climate-controlled Fitotron ${ }^{\circledR}$ plant growth chamber (Weiss Technik UK Ltd, Ebbw Vale, UK) with photoperiod of $16 \mathrm{~h} \mathrm{day}^{-1}$, light intensity of $350 \mu \mathrm{mol} \mathrm{m} \mathrm{m}^{-2} \mathrm{~s}^{-1}$, temperature of $15^{\circ} \mathrm{C}$ and relative humidity of $70 \%$. A single Rhizon ${ }^{\circledR}$ sampler (Rhizosphere Research Products, Wageningen, Netherlands) was inserted into the centre of each soil block to non-destructively recover soil solution. To label the plant-available $\mathrm{P}$ pool, $100 \mathrm{ml}$ of a solution containing ${ }^{33} \mathrm{P}\left(\mathrm{H}_{3}{ }^{33} \mathrm{PO}_{4}, 111 \mathrm{TBq} \mathrm{mmol}^{-1}\right.$; $1.23 \mathrm{kBq} \mathrm{ml}^{-1}$; American Radiolabeled Chemicals Inc., St Louis, MO) was evenly applied to the soil surface of each container two weeks before the flooding started.

The experiment had four distinct stages:

1. Pre-flood stage: This initial phase involved placing each plant-soil mesocosm $(n=16)$ into the growth chamber for 2 weeks to allow acclimation. The soils were maintained fieldmoist by the daily addition of oligotrophic river water (collected from the Aber River adjacent to where the soil samples were collected) based on their weight loss. This also permitted ${ }^{33} \mathrm{P}$ to become re-distributed within the plant-microbial-soil system;

2. Flood stage: This phase incorporated the four main flood treatments alongside an unflooded control treatment (maintained at field-moist based on weight loss), namely:

$\mathrm{T}_{1}$ : flooded soil with no above-ground vegetation and maintained in the dark [flood + dark (no veg.) treatment]

$\mathrm{T}_{2}$ : flooded soil with above-ground vegetation and maintained in the dark (flood + dark treatment)

$\mathrm{T}_{3}$ : flooded above-ground vegetation (from $\mathrm{T}_{1}$ ) with no soil and maintained in the dark [flood+dark (only veg.) treatment] 
$\mathrm{T}_{4}$ : flooded soil with above-ground vegetation and maintained in the light (flood+light

treatment)

$\mathrm{T}_{5}$ : unflooded soil with above-ground vegetation and maintained in the light (control+light treatment)

Firstly, the vegetation from 4 replicate containers was cut at ground level $\left(\mathrm{T}_{1}\right)$ and the grass clippings transferred to 4 new containers containing no soil $\left(T_{3}\right)$, increasing the number of containers up to 20. Secondly, river water was used to flood 16 of the containers $\left(T_{1}-T_{4}\right)$, including the four in which the grass was cut to soil level, and the four containing grass only. Each container received ca. $1200 \mathrm{ml}$ of river water to achieve a flood height of $10 \mathrm{~cm}$ above the soil surface (reflecting typical flood depths observed in the region during extreme weather events; Figs. S1-S3). Twelve containers were subsequently covered by black plastic prevent light entry into the microcosms $\left(\mathrm{T}_{1}-\mathrm{T}_{3}\right)$. Four microcosms were left unflooded and exposed to the light as a control $\left(\mathrm{T}_{5}\right)$. The floodwater was maintained at a constant height throughout the experiment through the addition of river water, while the unflooded control treatments were maintained field-moist as in the pre-flood phase. This phase lasted for 9 weeks.

3. Soil recovery stage: At this point in the experiment the flood water was carefully removed from treatments $T_{1}-T_{4}$. All treatments were then exposed to the light and ambient air and allowed to dry out naturally. This stage had a duration of 5 weeks and aimed to simulate the period before which agronomic practices recommenced.

4. Soil functions assessment stage: To evaluate any legacy effects of the flooding on soil functioning, a pot-based bioassay was performed. Briefly, $500 \mathrm{~g}$ of soil was recovered from each treatment (with roots removed) and placed in a $500 \mathrm{~cm}^{3}$ pot and sown with two $3 \mathrm{~d}$ old maize seedlings (Zea mays L.). The pots were placed in the same growth chamber as used above for $28 \mathrm{~d}$, except that the temperature was maintained at $20^{\circ} \mathrm{C}$. Thirty $\mathrm{ml}$ of a solution containing $\mathrm{N}, \mathrm{P}$ and $\mathrm{K}\left(10 \mathrm{mM} \mathrm{KNO} 3,15 \mathrm{mM} \mathrm{KH}_{2} \mathrm{PO}_{4}\right)$ were applied on a weekly basis to remove nutrient limitation. After $7 \mathrm{~d}$, one plant from each pot was removed. The pots were 
weighed and watered with river water 3 times per week to maintain the soils in a field-moist condition.

\subsection{Measurement of soil chemical and biological indicators}

\subsubsection{Element cycling and water quality}

Depending upon treatment and experimental stage, soil solution and floodwaters were collected approximately weekly and analysed for $\mathrm{pH}$, electrical conductivity (EC), total $\mathrm{Fe}$ (Loeppert and Inskeep, 1996), $\mathrm{Fe}^{2+}$ (Loeppert and Inskeep, 1996), P (Murphy and Riley, 1962), ${ }^{33} \mathrm{P}, \mathrm{NO}_{3}{ }^{-}$(Miranda et al., 2001), $\mathrm{NH}_{4}{ }^{+}$(Mulvaney, 1996), total dissolved $\mathrm{N}$ (TDN) and dissolved organic C (DOC). Additional samples were taken the day before and after the first and the last days of the flood stage. $\mathrm{Fe}, \mathrm{P}, \mathrm{NO}_{3}{ }^{-}$and $\mathrm{NH}_{4}{ }^{+}$were determined by spectrophotometry on a PowerWave XS microplate reader (BioTek Instruments Inc., Winooski, VT). TDN and DOC were determined using a Multi N/C 2100/2100 analyser (AnalytikJena AG, Jena, Germany). Dissolved organic N (DON) was calculated by subtraction of $\mathrm{NO}_{3}{ }^{-}$and $\mathrm{NH}_{4}{ }^{+}$from the TDN value. ${ }^{33} \mathrm{P}$ in solution was determined by liquid scintillation counting on a Wallac 1404 scintillation counter (Wallac EG\&G, Milton Keynes, UK) after mixing with Optiphase Hisafe 3 scintillation fluid (PerkinElmer Inc., Waltham, MA). Soil redox potential was determined periodically through the experiment using a SenTix $^{\circledR}$ probe (WTW Wissenschaftlich-Technische Werkstätten GmbH, Weilheim, Germany) inserted in the surface of the soil (0-3 cm depth).

During the flood stage, the total amount of nutrient released into the soil solution and overlying floodwater ( $\left.C_{\text {release }}\right)$ was calculated as follows:

$$
C_{\text {release }}\left(\mathrm{mg} \text { container }{ }^{-1}\right)=\left[C_{\text {sol }} \times V_{\text {soil }} \times \Theta\right]+\left[C_{\text {flood }} \times V_{\text {flood }}\right]
$$

where $C_{\text {sol }}$ and $C_{\text {flood }}$ are the concentration of nutrient in the soil solution and floodwater respectively, $V_{\text {soil }}$ and $V_{\text {flood }}$ are the volume of soil and floodwater respectively and $\Theta$ is the volumetric water content $\left(0.5 \mathrm{~cm}^{3} \mathrm{~cm}^{-3}\right)$. 


\subsubsection{Air quality}

Although some small $\mathrm{N}_{2} \mathrm{O}$ emissions from residual soil $\mathrm{NO}_{3}{ }^{-}$at the start of flooding were detected in a similar previous experiment (Sánchez-Rodríguez et al., 2017), the most important emissions were measured during the soil recovery phase (Sánchez-Rodríguez et al., 2017, 2018). This is the reason why we focused our GHGs measurements on the soil recovery stage. On the last day of the flood stage and through the flood recovery stage the mesocosms were hermetically sealed during the samplings (the day before the floodwater was removed, the same day after the floodwater was removed and weekly until the end of the soil recovery). At $0 \mathrm{~h}$ and $1 \mathrm{~h}$ after sealing (between $10.00 \mathrm{~h}$ and $12.00 \mathrm{~h}$ ), $20 \mathrm{ml}$ of headspace gas was removed using a hypodermic syringe via a rubber septum placed in the mesocosm lid, and the gas transferred to a pre-evacuated glass vial. $\mathrm{CH}_{4}, \mathrm{CO}_{2}$ and $\mathrm{N}_{2} \mathrm{O}$ concentrations in the vials were subsequently analysed by gas chromatography using a Clarus 500 GC equipped with a HS-40Turbomatrix headspace analyser, ${ }^{63} \mathrm{Ni}$ electron-capture detector and flame ionization detector connected to a methanizer (PerkinElmer Inc.). Fluxes were estimated as the difference in gas concentration at time 0 and $1 \mathrm{~h}$ and after correction for both temperature and the ratio between chamber volume and soil surface area (MacKenzie et al., 1998). Cumulative fluxes were estimated by linear interpolation, multiplying the mean of two successive daily fluxes by the number of hours between the two measurements and adding that amount to the previous cumulative total.

\subsubsection{Habitat provision and biological population regulation}

At the end of the soil recovery stage (second phase of the experiment), the dry weight of grass and number of earthworms per box were weighed and counted, respectively. Maize plant height was measured after 14 and $28 \mathrm{~d}$, plant dry weight was determined $\left(80^{\circ} \mathrm{C}, 72 \mathrm{~h}\right)$ and mineral element concentrations in above- and below-ground biomass determined by ICP-OES after dry-ashing and digestion with hydrochloric acid (Adrian, 1973) at the end of the soil 
functions assessment stage (fourth phase of the experiment), To evaluate changes in microbial community structure, soil samples $(25 \mathrm{~g})$ from each container were collected at the beginning and at the end of soil recovery stage and stored at $-80^{\circ} \mathrm{C}$ for PLFA analysis and subsequently determined as described in Bartelt-Ryser et al. (2005). Although a total of 50 fatty acids were 259

identified in the soil samples, Table 1 shows the 23 with a concentration higher than $0.5 \%$ of the total PLFAs that were used as biomarkers for the different taxonomic groups according to Ratledge and Wilkinson (1988), Bedard and Knowles (1989), Bowman et al. (1991, 1993), Kieft et al. (1994), Paul and Clark (1996), Bossio and Scow (1998), Olsson et al. (1999), Zelles (1999), Niklaus et al. (2003), Bartelt-Ryser et al. (2005) and using standard nomenclature as described in Frostegård et al. (1993). Despite their known limitations (Frostegård, 2011), the following PLFA biomarker ratios were calculated: fungi-to-bacteria as an indicator of large scale community shifts, predator-to-prey (protozoa/bacteria) to estimate the availability of nutrients to support higher trophic levels, Gram+-to-Gram- as an indicator of soil aeration state (Bossio and Scow, 1998), saturated-to-unsaturated fatty acids (sat/unsat) as an indicator of the stability of the microbial community, mono-to-polyunsaturated fatty acids (mono/poly), precursor-to-cyclopropane fatty acids (precursor/cyclopropane fatty acids; $16 \omega / 17$ cyclo and $18 \omega / 19$ cyclo) as indicators of high stress (Knivett and Cullen, 1965).

\subsection{Statistical analysis}

Repeated measured analysis of variance (RM of ANOVA) based on a completely randomized design with 4 treatments and 4 replications per treatment were applied to $\mathrm{pH}, \mathrm{EC}$, $\mathrm{Fe}, \mathrm{P},{ }^{33} \mathrm{P}, \mathrm{NH}_{4}^{+}, \mathrm{NO}_{3}{ }^{-}, \mathrm{DON}, \mathrm{DOC}$ in soil solution [flood+dark (no veg.), flood+dark, flood+light and control+light] and flood water [flood+dark (no veg.), flood+dark, flood+dark (only veg.) and flood+light] as well as for soil redox potential and daily GHG emissions during the soil recovery stage $[$ flood + dark (no veg.), flood + dark, flood + light and control+light]. Bonferroni multiple comparison test at a probability level of 0.05 was used to 
281 identify differences between treatments. ${ }^{33} \mathrm{P}(\%)$ is expressed as the ${ }^{33} \mathrm{P}$ of the sample $/{ }^{33} \mathrm{P}$ of 282 the original radioactive solution (accounting for radioactive decay) $\times 1000$ for soil solution samples and, additionally, multiplying by 13 only in the case of floodwater samples, because the initial $100 \mathrm{ml}$ of radioactive solution (applied to the soil of all containers) were diluted when 1.21 of fresh water were applied to flood+dark (no veg.), flood+dark and flood+light containers at the beginning of the flood-stage.

Analysis of variance (ANOVA) based on a completely randomized design with the same number of treatments and replications was applied to the plant biomass, plant nutrient content, earthworm, cumulative GHG, and PLFA data. In these cases, Tukey's HSD post hoc was used to identify treatment differences.

To identify relationships between soil microbial communities and GHG daily fluxes, soil redox potential, $\mathrm{NO}_{3}^{-}$and $\mathrm{NH}_{4}^{+}$in soil solution, and to find differences between treatments, principal component analysis (PCA) was performed at the end of the flood and soil recovery stages, based on a data correlation matrix to elucidate differences between treatments. Finally, Pearson correlations were carried out between these parameters using the data obtained during the soil recovery. The statistical analyses were performed using the statistical package SPSS software v22.0 (IBM Inc., Armonk, NY).

\section{Results}

3.1. Element cycling and water quality: Response of soil chemical indicators to extreme flooding

Few major treatment effects were observed in soil solution $\mathrm{pH}$, however, slightly higher soil solution $\mathrm{pH}$ values were obtained in the flood treatments [flood+dark(no veg.), flood + dark and flood + light] relative to the control+light treatment 3-5 weeks after flooding (Fig. 1a). The floodwater (Fig. 1b), pH values were similar to those of soil, with the exception of the flood+light treatment $\left(\mathrm{T}_{4}\right)$ which had a significantly higher $\mathrm{pH}$ relative to the dark-flood 
treatments $\left(\mathrm{T}_{1}\right.$ and $\left.\mathrm{T}_{2}\right)$.In contrast to $\mathrm{pH}$, major changes in soil EC and redox potential in response to flooding were observed (Fig. 1c-e). In all flood treatments, soil solution EC increased markedly during the experiment, especially during the flood stage, but quickly declined at the soil recovery stage (Fig. 1c). The increase in EC was slower in the illuminated flood treatment $\left(\mathrm{T}_{4}\right)$ relative to those maintained in the dark. In comparison to the soil, the EC of the floodwater remained lower with the highest values seen in the treatments containing soil and maintained in the dark (Fig. 1d). Redox potential rapidly declined in the flood treatments and then remained constant throughout the flood period (Fig. 1e). The redox potential remained consistently higher in the illuminated flood treatments in comparison to those maintained in the dark. After flood removal, the redox potential rapidly increased, reaching positive values again within ca. $7 \mathrm{~d}$ and values close to the non-flooded treatment control $\left(\mathrm{T}_{5}\right)$ by $21 \mathrm{~d}$.

The dynamics of $\mathrm{Fe}^{2+}$ (not shown) in soil solution and floodwater exhibited a similar temporal pattern to total Fe (Fig. 2ab) and represented $60 \%$ of the total Fe in soil solution and $65 \%$ of total $\mathrm{Fe}$ in flood water (averaged across the whole flooding period). Fe concentrations in soil solution rapidly increased after commencement of the flood treatment (albeit slower in $\mathrm{T}_{4}$ relative to $\mathrm{T}_{1}$ and $\mathrm{T}_{2}$ ), peaking at $\approx 29 \mathrm{mg} \mathrm{Fe}^{-1}$ at the end of flood stage (Fig. 2a). In comparison, soil solution Fe concentrations in the control treatment $\left(\mathrm{T}_{5}\right)$ remained low throughout the experiment. After flood removal, soil solution Fe in the flooded treatments rapidly dropped to values similar to the control. Significant amounts of Fe accumulated in floodwater albeit at lower concentration that observed in soil solution (Fig. 2b). Floodwater Fe concentrations in the flooded treatments containing soil started to increase after $7 \mathrm{~d}$, reaching maximal values by week 4 . In contrast, Fe concentrations remained very low when no soil and only vegetation was present $\left(\mathrm{T}_{3}\right)$. The potential Fe lost (mg mesocosm ${ }^{-1}$ ) was 14.8 \pm 0.4 in $\mathrm{T}_{1}$ [flood+dark (only veg.), $14.9 \pm 2.0$ in $\mathrm{T}_{2}$ (flood+dark) and $12.3 \pm 0.6$ in $\mathrm{T}_{4}$ (flood+light), being $0.5 \pm 0.1$ from the grass in $\mathrm{T}_{3}$ [flood+dark (only veg.)]. 

$\left.1^{-1}\right)$. Although a simple explanation is not possible, several spikes in soluble $\mathrm{P}$ were seen during the flood stage, however, few significant treatment effects were observed (Fig. 2c). This is supported by the data obtained for ${ }^{33} \mathrm{P}$ which also showed a very low $\mathrm{P}$ concentration and no significant differences between treatments (Fig. 2e). After flood removal, the amount of ${ }^{33} \mathrm{P}$ in soil solution was negligible $(<0.1 \%$ of the initial value). In contrast to soil solution, significant increases in both $\mathrm{P}$ and ${ }^{33} \mathrm{P}$ were observed in floodwater (Fig. 2df). Floodwater P concentrations were highest in treatments containing no soil ( $\mathrm{T}_{3}$, grass only) and significantly lower in the illuminated flood treatment $\left(\mathrm{T}_{4}\right)$. The calculated potential P loss from the soil (mg mesocosm $^{-1}$ ) was $0.6 \pm 0.2$ in $\mathrm{T}_{1}$ [flood + dark (no veg.)], $0.8 \pm 0.2$ in $\mathrm{T}_{2}$ (flood+dark) and 0.2 $343 \pm 0.1$ in $\mathrm{T}_{4}$ (flood+light). This value was higher for $\mathrm{T}_{3}$ (grass only) being $1.3 \pm 0.2 \mathrm{mg}$ $\operatorname{mesocosm}^{-1}$.

A similar pattern to Fe was observed for $\mathrm{NH}_{4}{ }^{+}$during flooding (Fig. 3a). In the control treatment $\left(\mathrm{T}_{5}\right), \mathrm{NH}_{4}{ }^{+}$concentrations remained low throughout the experiment $\left(<0.7 \mathrm{mg} 1^{-1}\right.$. The imposition of a flood, however, induced a progressive increase in $\mathrm{NH}_{4}{ }^{+}$concentration until the end of the flood stage. This was particularly evident in the flooded treatments without light $\left(\mathrm{T}_{1}, \mathrm{~T}_{2}\right)$ with $\mathrm{NH}_{4}{ }^{+}$concentrations increasing immediately after flooding. When

350 light was present $\left(\mathrm{T}_{4}\right)$, a significant lag phase in $\mathrm{NH}_{4}{ }^{+}$production occurred after flooding with the concentrations being much less than in the dark treatments. After flood removal, the $\mathrm{NH}_{4}^{+}$ concentrations initially fell in all treatments, however, this was greater when plants were present in the mesocosms. $\mathrm{NH}_{4}{ }^{+}$was only detected in the overlying floodwater in the dark 354 treatments (Fig. 3b). The calculated potential $\mathrm{NH}_{4}{ }^{+}$lost $\left(\mathrm{mg}\right.$ mesocosm $\left.{ }^{-1}\right)$ was considerably 355 higher in $\mathrm{T}_{1}[16.9 \pm 2.0$, dark + flood (no veg.) $]$ and $\mathrm{T}_{2}\left(15.4 \pm 1.0\right.$, dark + flood) than in $\mathrm{T}_{3}(2.7$ $356 \pm 1.3$, dark+flood [only veg. $)$ ] and $\mathrm{T}_{4}(4.3 \pm 2.0$, light + flood $)$. 
observed, especially in those mesocosms which had been previously maintained in the dark.

360 In comparison to $\mathrm{NH}_{4}{ }^{+}$, the levels of $\mathrm{NO}_{3}{ }^{-}$in floodwater were extremely low, however, significantly more was $\mathrm{NO}_{3}{ }^{-}$observed in the dark-flood treatments (Fig. 3d). Across all treatments, the loss of $\mathrm{NO}_{3}{ }^{-}$from the mesocosms was very low in the flooded treatments $\left(<1.1 \mathrm{mg}\right.$ mesocosm $\left.{ }^{-1}\right)$.

Overall, flooding induced both an increase in DON and DOC concentrations in soil solution over time relative to the unflooded control (Fig. 4c). Concentrations tended to be higher in the dark treatments. Once the floodwater had been removed, DOC concentrations rapidly declined within $14 \mathrm{~d}$, however, this decline was considerably slower for DON. Levels of DOC in floodwater increased over time, however, the dynamics and treatment effect were different to those seen in soil solution (Fig. 4d). In contrast, levels of DON in floodwater remained low with few treatments effects apparent (Fig. 4b). The potential DON lost (mg mesocosm $^{-1}$ ) was $28.3 \pm 2.4$ in $\mathrm{T}_{1}, 27.5 \pm 0.6$ in $\mathrm{T}_{2}$ and $14.7 \pm 0.8$ in $\mathrm{T}_{4}$ and the potential DOC lost $\left(\mathrm{mg} \mathrm{mesocosm}^{-1}\right)$ was $362 \pm 19$ in $\mathrm{T}_{1}, 352 \pm 20$ in $\mathrm{T}_{2}$ and $339 \pm 12$ in $\mathrm{T}_{4}$.

\subsection{Air quality: Greenhouse gas emissions}

Figure 5 shows the daily production and cumulative fluxes of $\mathrm{CH}_{4}, \mathrm{CO}_{2}$ and $\mathrm{N}_{2} \mathrm{O}$ from the last day of the flood stage and throughout the soil recovery stage. Daily $\mathrm{CH}_{4}$ fluxes were greatest at the end of flooding and rapidly declined after floodwater removal reaching fluxes close to background $20 \mathrm{~d}$ after flood removal, especially for $\mathrm{T}_{1}$ and $\mathrm{T}_{2}$ (more constant for $\mathrm{T}_{4}$, flooding in the light). The highest cumulative $\mathrm{CH}_{4}$ fluxes $(P=0.003)$ were found for treatment including floods $\left(\mathrm{T}_{1}>\mathrm{T}_{2}>\mathrm{T}_{4}>\mathrm{T}_{5}\right.$; Fig. 5b). Daily $\mathrm{CO}_{2}$ fluxes in the dark treatments were initially higher than the illuminated treatments both at the end of the flood stage and during soil recovery. This trend subsequently reversed after 2 weeks of soil recovery. Although the dynamics of $\mathrm{CO}_{2}$ production differed between treatments, the cumulative amount of $\mathrm{CO}_{2}$ produced over the recovery phase was similar (Fig. 5d). Daily 
$\mathrm{N}_{2} \mathrm{O}$ fluxes were highest in the darkened flood treatments $\left(\mathrm{T}_{1}\right.$ and $\left.\mathrm{T}_{2}\right)$ and showed a progressive production throughout the flood recovery stage (Fig. 5ef). When light was present in the flood stage then almost no $\mathrm{N}_{2} \mathrm{O}$ was produced, and responded in a near-identical way to the unflooded control.

\subsection{Habitat provision and biological population regulation}

\subsubsection{Vegetation responses to extreme flooding}

As expected, the fertile agricultural Eutric Cambisol had a high base saturation, high available $\mathrm{P}$ content, nitrification potential $\left(\mathrm{NO}_{3}{ }^{-}>\mathrm{NH}_{4}{ }^{+}\right.$; Table $\left.\mathrm{S} 1\right)$ and supported rapid sward growth in the absence of flooding. After imposing the flood treatments and in the absence of light, the vegetation was able to survive for approximately 3-4 weeks, however, beyond this point, senescence and subsequent decomposition of the above-ground biomass occurred $\left(T_{2}\right.$ and $\left.T_{3}\right)$. Little recovery of this grass occurred in the subsequent recovery period when the floodwater was removed and the soil allowed to dry out (Table 2). In contrast, when light was present $\left(\mathrm{T}_{4}\right)$, a considerable amount of the above-ground vegetation was able to survive throughout the flood period and readily recovered after floodwater removal. Despite this sward recovery, grass production in the flooded treatments was less than produced in the unflooded control $\left(\mathrm{T}_{5}\right)$.

No significant differences were observed for plant height, dry weight and mineral nutrient concentration in the maize crop in the bioassay performed at the end of the experiment (fourth phase). The only notable exceptions to this were the reduced growth for plants grown in the $\mathrm{T}_{1}$ [dark+flood (no veg.)] soil (SI, Table S2) and minimum alterations in foliar C and K (SI, Table S3).

\subsubsection{Soil mesofauna}


of the experiment, however, live earthworms could only be recovered from the soil of the unflooded controls (Table 2).

\subsubsection{Soil microbial biomass and community structure}

Microbial PLFA analysis after the flood phase (Fig. 6a) and after soil recovery (Fig. 6b) showed that flooding induced a significant reduction in biomass relative to the unflooded control. Microbial community structure was also significantly altered by flooding (Fig. $6 \mathrm{~cd}$ ). Overall, flooding significantly decreased the amount of PLFAs indicative of protozoa $(P=$ 0.014 and $P=0.002)$, putative arbuscular mycorrhizas $(P=0.004$ and $P=0.035)$ and fungi $(P$ $<0.001$ and $P<0.001)$, and increased the amount of Gram + bacteria $(P<0.001$ and $P=$ $0.005)$ and actinomycetes $(P=0.111$ and $P=0.047)$ in comparison with the unflooded control (after flood and soil recovery stages, respectively, in each case). The PLFA ratios were also altered by flooding, reducing fungi/bacteria $(P<0.001$ and $P<0.001)$, predator/prey $(P=$ 0.012 and $P=0.001)$ and $18 \mathrm{w} / 19$ cyclo $(P=0.043$ and $P=0.020)$ but increasing Gram $+/$ Gram- $(P=0.007$ and $P=0.032)$, sat/unsat $(P<0.001$ and $P=0.033)$ and mono/poly $(P<0.001$ and $P=0.002)$ (Fig. 6ef).

Figure 7 shows the relationships in PLFA between the treatments after the flood and soil recovery stages, i.e. taxonomic groups (Fig. 7ab) and fatty acids ratios (Fig. 7cd). These PCAs show clear separation between the control and flood treatments with the absence of light exacerbating the differences relative to the flooded treatment maintained in the light. At the end of the flood stage, the first three components of the PCA (Fig. 7a) explained $75.2 \%$ of the total variance. The first principal component (PC1) with a high loading for fungi, redox, protozoa, Gram + and $\mathrm{NH}_{4}{ }^{+}$accounted for $47.3 \%$; the PC2 that explained $13 \%$ of the variance (PC2) had a high loading for $\mathrm{NO}_{3}{ }^{-}$and $\mathrm{N}_{2} \mathrm{O}$. Some of the correlations of the variables used to do the PCA were: fungi-redox $(r=0.87, P<0.001)$, fungi- $\mathrm{NH}_{4}{ }^{+}(r=-0.89, P<0.001)$, fungi- 
Gram $+(r=-0.89, P<0.001)$, fungi- $\mathrm{CH}_{4}(r=-0.61, P=0.006)$, redox-Gram $+(r=-0.89, P<$ $0.001)$, and protozoa-Gram $+(r=-0.86, P<0.001)$.

At the end of the soil recovery stage (Fig. 7b), PC1 had a high loading for Gram+, actinomycetes (actino), fungi and anaerobic bacteria and explained $40 \%$ of the total variance while PC2 explained 21.2\%, with a high loading for Gram- bacteria followed by redox (79\% of total variance explained by the first 3 components). See Supp. Info for further information relating to Fig. $7 \mathrm{~cd}$.

Table 3 shows the correlation matrix between GHG daily fluxes and soil parameters during soil recovery stage. $\mathrm{CH}_{4}$ emissions were related with anaerobic conditions (low redox potential, high $\mathrm{NH}_{4}{ }^{+}$concentrations). Lastly, soil redox potential was negatively correlated to $\mathrm{NH}_{4}{ }^{+}$in soil solution (Table 3).

Additional correlations between PLFAs and the most abundant fatty acids $(>2 \%$ of the total PLFAs) and GHG daily fluxes, redox potential in soil, $\mathrm{NH}_{4}{ }^{+}$and $\mathrm{NO}_{3}{ }^{-}$are shown in Table 4. $\mathrm{CH}_{4}$ emissions were negatively correlated with PLFAs and the majority of these fatty acids after the flood stage only. These negative correlations also occurred for $\mathrm{NH}_{4}{ }^{+}$after both stages. $\mathrm{CO}_{2}$ emission was negatively correlated with total PLFAs and many individual fatty acids after the flooding stage but were positively related after the soil recovery stage (Table 4). As expected, redox potential in the soil was positively correlated with PLFAs in both stages, indicating a higher microbial activity in the soil when redox potential is positive.

\section{Discussion}

This study clearly demonstrated that when soils with no previous history of flooding are subjected to intense waterlogging, major changes in soil functions and ecosystem service delivery occur. The simulated flood typologies reflect those seen recently in the UK and elsewhere around the world (Dodds, 2014; Hai et al., 2017; Romshoo et al., 2018). 
As expected, the vegetation in our mesocosms was heavily affected by long-term

464 flooding, especially when light was restricted (Mommer et al., 2005a, b; Das et al., 2009).

465 This suggests that alongside flood duration (Fig. S1-S4), the typology of the flood event is 466 also critical in determining the likelihood of vegetation survival. Extreme flooding can be

467

468

469

470

471

472

473 associated with large amounts of turbid sediment in the overlying water which restricts light penetration (Fig. S3), whilst other flood events are associated with groundwater rise and relatively clear overlying waters (Fig. S4). In recent years, extreme flood events in the UK have been associated with large amounts of sediment in the floodwater which remains suspended for long time periods via wind-mediated turbulence (Fig. S5). The impact of light restriction and sediment load therefore requires greater consideration in future studies on the impact of flooding on plant-soil systems (Squires et al., 2002). It is also clear from our study that the presence of light favoured a more rapid recovery of grass production 5 weeks after floodwater removal, however, no significant differences were observed in maize sown after the soil recovery period in any treatment, highlighting the capacity of the soil to selfameliorate.

Earthworms perform vital functions in grasslands including the promotion of soil organic matter turnover, nutrient recycling, aeration, drainage and the amelioration of compaction (Langmaack et al., 1999). All of these attributes are frequently linked to greater primary productivity. A decline in earthworm abundance, diversity or activity can therefore be viewed as a severe loss of soil quality (Coyle et al., 2017). In our experiments, long-term flooding resulted in a complete loss of the earthworm population with no recovery (i.e. hatching from cocoons) observed 5 weeks after floodwater removal. This is in general agreement with Ivask et al. (2012) who suggested that earthworm populations were particularly affected by long term flooding. The loss of earthworms from all flooding treatments in comparison with the unflooded controls could have potential short and longterm effects on soil functionality (e.g. the loss of fertility, and a decline in soil structure). 
4.2. Impact of flooding on element cycling, water and air quality

In our study, flooding increased soil $\mathrm{pH}$, consistent with previous studies in rice paddy soils and salt marshes by Ponnamperuma (1972) and Negrin et al. (2011), however, the overall effect was small. We conclude that this is unlikely to cause lasting changes in nutrient bioavailability or explain our flood-induced shifts in microbial diversity. A clear negative effect of flooding on EC was apparent, however, the levels were insufficient to induce osmotic stress in roots. We attribute the increase in EC to the release of mineral elements from soil and during vegetation senescence (e.g. Fe, $\mathrm{P}, \mathrm{NH}_{4}{ }^{+}$).

Flooding significantly altered the redox conditions in the soil, with all flood treatments rapidly becoming anaerobic (Reddy and De Laune, 2008). However, the vegetation in $\mathrm{T}_{4} \mathrm{kept}$ redox values higher than in $T_{1}$ and $T_{2}$ (without vegetation and in which vegetation died after 3-4 weeks of flood, respectively), probably because the plants were able to deliver oxygen to the rhizosphere, alleviating the anaerobic conditions to some extent. Although this effect has been observed for plant species such as Spartina alterniflora (Colmer, 2003), other authors found no influence of vegetation on redox potential in soil with highly reduced conditions (Negrin et al., 2011). This supports the tenet that selection of grass varieties with greater potential for aerenchyma formation will offer greater protection against long term flooding (de Souza et al., 2017).

The different element cycles (partially) assessed in this study were altered considerably. There was a clear effect of flooding on Fe release (soil solution and floodwater), however, a less clear pattern was apparent for $\mathrm{P}$ because the increase of $\mathrm{P}$ was only observed in the floodwater of $T_{2}$ and $T_{3}$, treatments with vegetation and under light restrictions. We had hypothesized that $\mathrm{P}$ held on the surface of Fe-oxyhydroxides would be released under reducing conditions and would migrate upwards to the overlying floodwater where it might stimulate algal production (Nanzyo et al., 2004; Heiberg et al., 2010), however, this was not 
apparent. This could be due to any P released being reabsorbed back onto Al-hydroxides or being immobilized by the microbial biomass. The evidence from the ${ }^{33} \mathrm{P}$ tracers also indicated that the majority of solubilised $\mathrm{P}$ in the floodwater was actually derived from the decomposing grass. Based on our field observations, it is also possible that Fe-P minerals may have formed directly at the soil surface where the conditions are less anoxic (Lindsay et al., 1989; Roden and Edmonds, 1997). The potential for P and Fe redistribution in soil during flooding therefore warrants further research.

We ascribe the net accumulation of $\mathrm{NH}_{4}{ }^{+}$during flooding to the mineralization of soil organic matter $\left(T_{1}\right)$, the necrosis of plant tissues and an inhibition of nitrification (Nielsen et al., 1996). In the case of the soil, we cannot distinguish between $\mathrm{N}$ released from microbial processes or from autolysis of live roots and subsequent excretion of $\mathrm{NH}_{4}^{+}$(Marella et al., 2017). The low C:N ratio of earthworms (ca. 3:1) and vegetation (ca. 24:1) is likely to favour net $\mathrm{NH}_{4}{ }^{+}$release during their decomposition (Zheng and Marschner, 2017). In addition, when photosynthesis is restricted and $\mathrm{C}$ for plant respiration becomes limited, root and shoot autolysis will commence leading to $\mathrm{NH}_{4}{ }^{+}$excretion to the external medium (i.e. during proteolysis and creation of organic/keto acids; Marella et al., 2017). This operation of this pathway is supported by the greater release of soluble $\mathrm{N}$ in treatments where light was restricted. The $\mathrm{NH}_{4}{ }^{+}$concentration in floodwater of $\mathrm{T}_{2}$ during the flood stage was approximately the sum of the concentrations of $\mathrm{T}_{1}$ (soil without above-ground vegetation) and $\mathrm{T}_{3}$ (vegetation from $\mathrm{T}_{1}$ ) treatments (Fig. 3b). This suggests that $35-40 \%$ of the $\mathrm{NH}_{4}^{+}$ originated from the above-ground vegetation and 60-65 \% from the soil compartment. In addition to plant uptake, losses of $\mathrm{NH}_{4}{ }^{+}$via $\mathrm{NH}_{3}$ volatilization (not determined in this experiment) could also have occurred under inundation (Zhong-Cheng et al., 2012; Chen et al., 2015). The high $\mathrm{pH}$ of the floodwater ( $\mathrm{pH}$ 7.0-8.5) would favour this loss pathway and could help explain the decrease in $\mathrm{NH}_{4}{ }^{+}$for $\mathrm{T}_{1}, \mathrm{~T}_{2}$ and $\mathrm{T}_{3}$ in the overlying water at the end of the flood stage. During soil recovery, the soil water content of $T_{1}, T_{2}$ and $T_{4}$ decreased, 
resulting in re-aeration of the soil, re-establishment of nitrification, leading to a decrease in $\mathrm{NH}_{4}{ }^{+}$, and increases in $\mathrm{NO}_{3}{ }^{-}$and $\mathrm{N}_{2} \mathrm{O}$ production.

Significant amounts of DOC and DON accumulated in the soil and overlying water during flooding. This can be attributed to the release of organic compounds from organisms killed by either (i) a lack of $\mathrm{O}_{2}$ (e.g. mesofauna), (ii) osmotic shock, or (iii) metal toxicity (e.g. by $\mathrm{Fe}^{2+}, \mathrm{Mn}^{2+}$ ) (Kieft et al., 1987, 1994; Denef et al., 2001; Fierer and Schimel, 2003). Based on the very high DOC-to-DON ratio (>70:1), however, we hypothesize that this $\mathrm{C}$ is mainly derived from anaerobic respiration by-products (e.g. ethanol, organic acids) excreted by plants and microbes into the external medium (Jones et al., 2009). Although soluble C could also be released during the reduction and solubilisation of Fe-oxyhydroxides, this is not favoured based on the DOC-to-DON ratio of soluble $\mathrm{C}$ held on the exchange surfaces of this soil (ca. 12:1; Jones and Willett, 2006). The measured decrease in DOC concentration following the removal of floodwater is most probably related to the removal of $\mathrm{O}_{2}$ limitation and a stimulation of microbial activity (Frank et al., 2014).

Although we used minimally disturbed blocks of vegetated soil in our mesocosms, some aspects of real flood events could not be replicated. For example, in our experiment there was no water turbulence and no erosional loss of soil, and the soil blocks were only 10 $\mathrm{cm}$ deep. While this reflects the main rooting zone, our results cannot be extrapolated easily to subsoils where the $\mathrm{C}$ content and root density is much lower, and the effects of flooding may be less severe. However, the nutrient losses due to the different flood typologiesaggravated under light restriction - indicate the importance of considering the origin of the floodwater, i.e. whether it contains suspended particles.

Alterations in the assessed gaseous emissions from the flooded mesocosms were also dependent on flood typology. Normally, very low emissions of $\mathrm{CO}_{2}, \mathrm{CH}_{4}$ and $\mathrm{N}_{2} \mathrm{O}$ have been observed during flooding in previous experiments with this soil (Sánchez-Rodríguez et al., 2017). $\mathrm{CH}_{4}$ emissions were, however, detected immediately after floodwater removal. We 
ascribe this to the release of $\mathrm{CH}_{4}$ produced during flooding, but which had become trapped within the soil pores until floodwater removal (Moore and Roulet, 1993; Sánchez-Rodríguez et al., 2017). In our experiment, the prevailing conditions under flooding (-100 mV redox potential, high DOC, senescing vegetation) were ideal for $\mathrm{CH}_{4}$ production (Hou et al., 2000). This was most apparent in the dark treatments where plant senescence was greatest. As oxygen was introduced back into the soil after flooding, and as alternative electron acceptors became available (e.g. $\mathrm{NO}_{3}{ }^{-}$), the rate of $\mathrm{CH}_{4}$ emissions quickly decreased (Yuan et al., 2008). This might also have been facilitated by an increase in $\mathrm{CH}_{4}$ oxidation within the soil (Zhang et al., 2012).

At the start of the soil recovery stage, the soil solution in the flooded treatments $\left(T_{1}, T_{2}\right.$ especially, and $\mathrm{T}_{4}$ ) had high concentrations of labile $\mathrm{N}$ and $\mathrm{C}$ (i.e. $\mathrm{NH}_{4}{ }^{+}, \mathrm{DON}$ and DOC). In addition, the soil redox potential increased, favouring conditions to produce $\mathrm{N}_{2} \mathrm{O}$ (Hou et al., 2000; Kim et al., 2010) as an intermediate product of nitrification. The observed decrease in soil solution $\mathrm{NO}_{3}{ }^{-}$concentration during the soil recovery stage also indicates losses via denitrification. However, the recovering vegetation under non-light restrictions could also have acted as a $\mathrm{NO}_{3}{ }^{-}$sink, contributing to the daily and cumulative fluxes of $\mathrm{N}_{2} \mathrm{O}$, being significantly lower for $T_{4}$ (flood+light) and $T_{5}$ or control in comparison with $T_{1}$ and $T_{2}$ (flood + dark without and with vegetation, respectively). Again, light restriction (flood typology) and the presence of grass were essential to understand gaseous $\mathrm{C}$ and $\mathrm{N}$ losses. Finally, it should be mentioned that, the limited depth of the mesocosms $(10 \mathrm{~cm})$ could have underestimated the gas fluxes measured during the 5 weeks after the floodwater removal as compared to field conditions but further research is needed to confirm this.

\subsection{Microbial biodiversity: Biological population regulation}

We present clear evidence that the microbial community was significantly affected by prolonged flooding, the presence of vegetation and time since flooding. However, in some 
593 flooding situations, water percolates through the soil in either an upward (groundwater

594 flooding) or downward (surface water flooding) direction. This mass flow may remove

595

596

597

598

599

600

601

602

603

604

605

606

607

608

609

610

611

612

613

614

615

616

617

618

microbial end-products and also change the redox status of the soil in comparison to our mesocosms where no mass flow occurred.

Our results are in general agreement with Ferré et al. (2012) who found a higher Gram+/Gram- bacteria ratio in flooded soils, probably as Gram+ bacteria (branched fatty acids) are believed to be more stress tolerant than Gram - bacteria (monounsaturated fatty acids). In addition, our results are in line with Reichardt et al. (2001) who found higher concentrations of fungi in non-flooded conditions in comparison with flooded soils. In most cases, however, the change in the individual amount of PLFAs was small in the different treatments. However, it should be noted that this mainly reflects changes in the active microbial biomass which may only represent $<10 \%$ of the total PLFA in soil. The impact of these changes in community structure on soil functioning remain uncertain due to the large functional redundancy that exists in soil. What is clear, however, is that it had little impact on plant growth and soil performance in our maize bioassay undertaken at the end of the experiment. Further, in comparison to the loss of earthworms we expect that small shifts in microbial community structure are of less importance in the longer term.

Other PLFA ratios were affected by the prolonged flooding treatments, for example the ratio of sat/unsat agrees with the increase in saturated fatty acids under flooding described in Bossio and Scow (1998), and 16w/17 cyclo and 18w/19 cyclo ratios that are related with stress (Knivett and Cullen, 1965), probably due to low $\mathrm{O}_{2}$ availability in the flooded treatments. The detection of 16:1w7c and 18:1w9c fatty acids in soil taken at the end of the flood period supports the presence of methanotrophs (Bedard and Knowles, 1989; Bowman et al., 1991, 1993).

Lastly, the role of surviving vegetation in $\mathrm{T}_{4}$ (flood+light, that facilitated less extreme flood conditions) produced an intermediate PLFA profile between $\mathrm{T}_{1}-\mathrm{T}_{2}$ (flood under 
darkness without and with soil, respectively) and $\mathrm{T}_{5}$ (unflooded controls; Figs. 6, 7). The oxygenation of the rhizosphere by living roots and a higher potential redox in $T_{4}$ (flood+light), probably lessened the impact of flooding and facilitated a quicker recovery of the microbial community.

\section{Conclusions}

Prolonged flood events were shown to induce major shifts in the size and structure of the soil microbial community that led to a decrease in air quality (higher net GHG emissions; $\mathrm{CH}_{4}, \mathrm{~N}_{2} \mathrm{O}$ ) and major alterations in soil biogeochemical cycling as a function of the flood typology. Prolonged flooding in which light is restricted increased the severity of the damage in terms of potential nutrient losses, GHG emissions, soil microbial communities, grass production and speed of recovery, highlighting the key role of the vegetation in maintaining grassland soil functioning. We demonstrated that the decomposition of vegetation is an important source of P loss, especially in flood typologies in which light is restricted where its contribution can be as important as soil in terms of $\mathrm{P}$ loss rates. Our results also suggest that anoxia-tolerant vegetation may play a key role in ameliorating the negative effects of flooding on habitat provision, element cycling, and biological population regulation.

\section{Acknowledgments}

This work was supported by the Project 'Legacy effects of the extreme flood events on soil quality and ecosystem functioning', NERC Grant Reference NE/M005143/1, by the UK Department for Environment, Food and Rural Affairs (DEFRA) project LM0316, by the UK Natural Environment Research Council (NE/I012303/1) and the Sêr Cymru LCEE-NRN project, Climate-Smart Grass. Sánchez-Rodríguez also acknowledges funding support by the 'Fundación Ramón Areces' for his postdoctoral scholarship “Beca para ampliación de estudios en el extranjero en materia de Ciencias de la Vida y de la Materia”. 


\section{References}

649

Adrian, W.J., 1973. A comparison of a wet pressure digestion method with other commonly used wet and dry-ashing methods. Analyst 98, 213-216.

Allan, R.P., 2011. Human influence on rainfall. Nature 470, 344-345.

Bartelt-Ryser, J., Joshi, J., Schmid, B., Brandl, H., Balser, T., 2005. Soil feedbacks of plant diversity on soil microbial communities and subsequent plant growth. Perspectives in Plant Ecology, Evolution and Systematics 7, 27-49.

Bedard, C., Knowles, R., 1989. Physiology, biochemistry, and specific inhibitors of $\mathrm{CH}_{4}$, $\mathrm{NH}_{4}^{+}$, and $\mathrm{CO}$ oxidation by methanotrophs and nitrifiers. Microbiology Reviews 53, $68-84$.

Bossio, D.A., Scow, K.M., 1998. Impacts of carbon and flooding on soil microbial communities: phospholipid fatty acid profiles and substrate utilization patterns. Microbial Ecology 35, 265-278.

Bowman, J.P., Skerratt, J.H., Nichols, P.D., Sly, L.I., 1991. Phospholipid fatty-acid and lipopolysaccharide fatty-acid signature lipids in methane-utilizing bacteria. FEMS Microbiology Ecology 85, 15-22.

Bowman, J.P., Sly, L.I., Nichols, P.D., Hayward, A.C., 1993. Revised taxonomy of the methanotrophs - description of methylobacter gen-nov, emendation of methylococcus, validation of methylosinus and methylocystis species, and a proposal that the family methylococcaceae includes only the group-I methanotrophs. International Journal of Systematic Bacteriology 43, 735-753. 
Brun, J., Barros, A.P., 2013. Vegetation activity monitoring as an indicator of ecohydrological impacts of extreme events in the southeastern USA. International Journal of Remote Sensing 34, 519-544.

Bünemann, E.K., Bongiorno, G., Bai, Z., Creamer, R.E., de Deyn, G., de Goede R., Fleskens, L., Geissen, V., Kuyper, T.W., Mäder, P., Pulleman, M., Sukkel, W., van Groenigen, J.W., Brussaard, L., 2018. Soil quality - A critical review. Soil Biology and Biochemistry 120, 105-125.

Chen, A., Lei, B., Hu, W., Lu, Y., Mao, Y., Duan, Z., Shi, Z., 2015. Characteristics of ammonia volatilization on rice grown under different nitrogen application rates and its quantitative predictions in Erhai Lake Watershed, China. Nutrient Cycling in Agroecosystems 101, 139-152.

Clout, H., 2014. Reflections on the draining of the Somerset Levels. The Geographical Journal 180, 338-341.

Colmer, T.D., 2003. Long-distance transport of gases in plants: a perspective on internal aeration and radial oxygen loss from roots. Plant Cell and Environment 26, 17-36.

Coyle, D.R., Nagendra, U.J., Taylor, M.K., Campbell, J.H., Cunard, C.E., Joslin, A.H., Mundepi, A., Phillips, C.A., Callaham, M.A., 2017. Soil fauna responses to natural disturbances, invasive species, and global climate change: Current state of the science and a call to action. Soil Biology and Biochemistry 110, 116-133.

Das, K.K., Panda, D., Sarkar, R.K., Reddy, J.N., Ismail, A.M., 2009. Submergence tolerance in relation to variable floodwater conditions in rice. Environmental and Experimental Botany 66, 425-434.

de Souza, K.R.D., Santos, M.D., Andrade, C.A., da Silva, D.M., Campos, N.A., Alves, J.D., 2017. Aerenchyma formation in the initial development of maize roots under waterlogging. Theoretical and Experimental Plant Physiology 29, 165-175. 
Denef, K.J., Six, J., Bossuyt, H., Frey, S.D., Elliot, E.T., Merckx, R., Paustian, K., 2001. Influence of dry-wet cycles on the interrelationship between aggregate, particulate organic matter, and microbial community dynamics. Soil Biology and Biochemistry 33, 1599-1611.

Dodds, K., 2014. Apres le deluge: the UK winter storms of 2013-14. Geographical Journal 180, 294-296.

Doran, J.W., Parkin, T.B., 1994. Defining and assessing soil quality. In: Doran, J.W., Coleman, D.C., Bezdicek, D.F., Stewart, B.A. (Eds.), Defining Soil Quality for a Sustainable Environment. SSSA, Madison, WI, pp. 3-21.

Doran, J.W., Parkin, T.B., 1996. Quantitative indicators of soil quality: a minimum data set. In: Doran, J.W., Jones, A.J. (Eds.), Methods for Assessing Soil Quality. Soil Science Society of America, Madison, WI, pp. 25-37.

Easterling, D.R., Meehl, G.A., Parmesan, C., Changnon, S.A., Karl, T.R., Mearns, L.O., 2000. Climate extremes: Observations, modeling, and impacts. Science 289, 2068-2074.

Ferré, C., Zechmeister-Boltenstern, S., Comolli, R., Andersson, M., Seufert, G., 2012. Soil microbial community structure in a rice paddy field and its relationships to $\mathrm{CH}_{4}$ and $\mathrm{N}_{2} \mathrm{O}$ fluxes. Nutrient Cycling in Agroecosystems 93, 35-50.

Fierer, N., Schimel, J.P., 2003. A proposed mechanism for the pulse in carbon dioxide production commonly observed following the rapid rewetting of a dry soil. Soil Science Society of America Journal 67, 798-805.

Frank, S., Tiemeyer, B., Gelbrecht, J., Freibauer, A., 2014. High soil solution carbon and nitrogen concentrations in a drained Atlantic bog are reduced to natural levels by 10 years of rewetting. Biogeosciences 11, 2309-2324.

Frostegård, Å, Tunlio, A., Bååth, E., 2011. Use and misuse of PLFA measurements in soils. Soil Biology and Biochemistry 43, 1621-1625. 
Frostegård, Å., Bååth, E., Tunlid, A., 1993. Shifts in the structure of soil microbial communities in limed forests as revealed by phospholipid fatty acid analysis. Soil Biology and Biochemistry 25, 723-730.

Giesler, R., Lundström, U.S., 1993. Soil solution chemistry: The effects of bulking soil samples and spatial variation. Soil Science Society of America Journal 57, 1283-1288.

Hai, O.S., Abu Samah, A.,Chenoli, S.N., Subramaniam, K., Mazuki, M.Y.A., 2017. Extreme Rainstorms that Caused Devastating Flooding across the East Coast of Peninsular Malaysia during November and December 2014. Weather and Forecasting 32, 49-872.

Heiberg, L., Pedersen, T.V., Jensen, H.S., Kjaergaard, C., Hansen, H.C.B., 2010. A comparative study of phosphate sorption in lowland soils under oxic conditions. Journal of Environmental Quality 39, 734-743.

Hou, A.X., hen, G.X., Wang, Z.P., Van Cleemput, O., Patrick Jr., W.H., 2000. Methane and nitrous oxide emissions form a rice field in relation to soil redox and microbiological processes. Soil Science Society of America Journal 64, 2180-2186.

Ivask, M., Meriste, M., Kuu, A., Kutti, S., Sizov, E., 2012. Effect of flooding by fresh and brackish water on earthworm communities along Matsalu Bay and the Kasari River. European Journal of Soil Biology 53, 11-15.

Jones, D.L., Nguyen, C., Finlay, R.D., 2009. Carbon flow in the rhizosphere: carbon trading at the soil-root interface. Plant and Soil 321, 5-33.

Jones, D.L., Willett, V.B., 2006. Experimental evaluation of methods to quantify dissolved organic nitrogen (DON) and dissolved organic carbon (DOC) in soil. Soil Biology and Biochemistry 38, 991-999.

Jones, M.R., Fowler, H.J., Kilsby, C.G., Blenkinsop, S., 2012. An assessment of changes in seasonal and annual extreme rainfall in the UK between 1961 and 2009. International Journal of Climatology 33, 1178-1194. 
Kieft, T.E., Soroker, E., Firestone, M.K., 1987. Microbial biomass response to a rapid increase in water potential when dry soil is wetted. Soil Biology \& Biochemistry 19, $119-126$.

Kieft, T.L., Ringelberg, D.B., White, D.C., 1994. Changes in ester linked phospholipid fatty acid profiles of subsurface bacteria during starvation and desiccation in a porous medium. Applied and Environmental Microbiology 60, 3292-3299.

Kim, D.G., Mishurov, M., Kiely, G., 2010. Effect of increased $\mathrm{N}$ use and dry periods on $\mathrm{N}_{2} \mathrm{O}$ emission from fertilized grasslands. Nutrient Cycling in Agroecosystems 88, 397-410.

Knivett, V.A., Cullen, J., 1965. Some factors affecting cyclopropane acid formation in Escherichia coli. Biochemical Journal 96, 771-776.

Langmaack, M., Schrader, S., Rapp-Bernhardt, U., Kotzke, K., 1999. Quantitative analysis of earthworm burrow systems with respect to biological soil-structure regeneration after soil compaction. Biology and Fertility of Soils 28, 219-229.

Lindsay, W.L., Vlek, P.L.G., Chien, S.H., 1989. Phosphate minerals. In: Dixon, J.B., Weed, S.B. (Eds.), Minerals in soil environments. Soil Science Society of America, Madison, WI, pp. 1089-1130.

Loeppert, R.H., Inskeep, W.P., 1996. Iron. In: Sparks, D.L. (Ed.), Methods of Soil Analysis. Part 3. Chemical Methods. ASA/SSSA, Madison, pp. 639-664.

MacKenzie, A.F., Fan, M.S., Cadrin, F., 1998. Nitrous oxide emission in three years as affected by tillage, corn-soybean-alfalfa rotations, and nitrogen fertilization. Journal of Environmental Quality 27, 698-703.

Marella, V.S.S.R., Roberts, P., Hill, P.W., Jones, D.L., 2017. Different ways in which $\mathrm{CO}_{2}$ can be released during the turnover of roots in soil. Biology and Fertility of Soils 53, $369-374$.

McEwen, L.J., Jones, O., Robertson, I., 2014. 'A glorious time?' Some reflections on flooding in the Somerset Levels. Geographical Journal 180, 326-337. 
Met Office - United Kingdom, 2014. The Recent Storms and Floods in the UK. Available at:http://www.http://nora.nerc.ac.uk/id/eprint/505192/1/N505192CR.pdf （10th June 2018)

Miranda, K.M, Espey, M.G., Wink, D.A., 2001. A rapid simple spectrophotometric method for simultaneous detection of nitrate and nitrite. Nitric Oxide: Biology and Chemistry 5, $62-71$.

Mommer, L., de Kroon, H., Pierik, R., Bogemann, G.M., Visser, E.J.W., 2005b. A functional comparison of acclimation to shade and submergence in two terrestrial plant species. New Phytologist 167, 197-206.

Mommer, L., Pons, T.L., Wolters-Arts, M., Venema, J.H., Visser, E.J.W., 2005a. Submergence-induced morphological, anatomical, and biochemical responses in a terrestrial species affect gas diffusion resistance and photosynthetic performance. Plant Physiology 139, 497-508.

Moore, T.R., Roulet, N.T., 1993. Methane flux - water-table relations in northern wetlands. Geophysical Research Letters 20, 587-590.

Mulvaney, R.L., 1996. Nitrogen - inorganic forms. In: Sparks, D.L. (Ed.), Methods of Soil Analysis. Part 3. Chemical Methods. Soil Science Society of America, Madison, WI, pp. 1123-1184.

Murphy, J., Riley, J.P., 1962. A modified single solution method for the determination of phosphate in natural waters. Analytica Chimica Acta 27, 31-36.

Murphy, J.M., Sexton, D.M.H., Jenkins, G.J., Boorman, P., Booth, B., Brown, K., Clark, R., Collins, M., Harris, G., Kendon, L., 2009. UK climate projections science report: Climate change projections. Met Office Hadley Centre, Exeter, UK.

Nanzyo, M., Kanno, H., Obara, S., 2004. Effect of reducing conditions on P sorption of soils. Soil Science and Plant Nutrition 50, 1023-1028. 
Natural England, 2014. An assessment of the effects of the 2013-14 flooding on the wildlife and habitats of the Somerset levels and moors: Report JP007. Natural England, Worcester.

Negrin, V.L., Spetter, C.V., Asteasuain, R.O., Perillo, G.M.E., Marcovecchio, J.E., 2011. Influence of flooding and vegetation on carbon, nitrogen, and phosphorus dynamics in the pore water of a Spartina alterniflora salt marsh. Journal of Environmental Science $23,212-221$.

Nelson, R.E., 1982. Carbonate and gypsum. In: Page, A.L. (Ed.), Methods of Soil Analysis. Part 2. Chemical and Microbiological Properties. Soil Science Society of America, Madison, WI, pp. 181-197.

Nielsen, T.H., Nielsen, L.P., Revsbech, N.P., 1996. Nitrification and coupled nitrificationdenitrification associated with a soil-manure interface. Soil Science Society of America Journal 60, 1829-1840.

Niklaus, P.A., Alphei, J., Ebersberger, D., Kampichler, D., Kandeler, E., Tscherko, D., 2003. Six years of in situ $\mathrm{CO}_{2}$ enrichment evoke changes in soil structure and soil biota of nutrient-poor grassland. Global Change Biology 9, 585-600.

Niu, S., Luo, Y., Li, D., Cao, S., Xia, J., Li, J., Smith, M.D., 2014. Plant growth and mortality under climatic extremes: An overview. Environmental and Experimental Botany 98, $13-19$.

Norton, J.M., 2008. Nitrification in agricultural soils, in: Schepers, J.S., Raun, W.R. (Eds.), Nitrogen in Agricultural Systems. Agron. Monogr. 49. American Society of Agronomy, Crop Science Society of America, Soil Science Society of America, Madison, WI, (Ch. 6), pp. 173-199.

Olsson, P.A., Thingstrup, I., Jakobsen, I., Baath, F., 1999. Estimation of the biomass of arbuscular mycorrhizal fungi in a linseed field. Soil Biology and Biochemistry 31, 1879-1887. 
Pall, P., Aina, T., Stone, D.A., Stott, P.A., Nozawa, T., Hilberts, A.G.J., Lohmann, D., Allen, M.R., 2011. Anthropogenic greenhouse gas contribution to flood risk in England and Wales in autumn 2000. Nature 470, 382-385.

Palomo, L., Claaseen, N., Jones, D.L., 2006. Differential mobilization of $\mathrm{P}$ in the maize rhizosphere by citric acid and potassium citrate. Soil Biology and Biochemistry 38, $683-692$.

Paul, E.A., Clark, F.E., 1996. Soil Microbiology and Biochemistry. Academic Press, San Diego, CA.

Ponnamperuma, F.N., 1972. The Chemistry of Submerged Soils. Academic Press, New York.

Ratledge, C., Wilkinson, S.G., 1988. Microbial Lipids. Academic Press, London.

Reddy, K.R., De Laune, R.D., 2008. Biogeochemistry of wetlands: science and applications. CRC Press, Boca Raton, FL.

Reichardt, W., Briones, A., de Jesus, R., Padre, B., 2001. Microbial population shifts in experimental rice systems. Applied Soil Ecology 17, 151-163.

Roden, E.E., Edmonds, J.W., 1997. Phosphate mobilization in iron-rich anaerobic sediments: microbial Fe (III) oxide reductions versus iron-sulphide formation. Archives of Hydrobiology 139, 347-378.

Romshoo, SA., Altaf, S., Rashid, I., Dar, R.A., 2018. Climatic, geomorphic and anthropogenic drivers of the 2014 extreme flooding in the Jhelum basin of Kashmir, India. Geomatics Natural Hazards \& Risk 9, 224-248.

Sánchez-Rodríguez, A.R., Chadwick, D.R., Tatton, G.S., Hill, P.W., Jones, D.L., 2018. Comparative effects of prolonged freshwater and saline flooding on nitrogen cycling in an agricultural soil. Applied Soil Ecology 125, 56-70 https://doi.org/10.1016/j.apsoil.2017.11.022. 
Sánchez-Rodríguez, A.R., Hill, P.W., Chadwick, D.R., Jones, D.L., 2017. Crop residues exacerbate the negative effects of extreme flooding on soil quality. Biology and Fertility of Soils 53, 751-765

Scalenghe, R., Edwards, A.C., Barberis, E., 2007. Phosphorus loss in overfertilized soils: the selective $\mathrm{P}$ partitioning and redistribution between particle size separates. European Journal of Agronomy 27, 72-80.

Scalenghe, R., Edwards, A.C., Barberis, E., Ajmone-Marsan, F., 2012. Are agricultural soils under a continental temperate climate susceptible to episodic reducing conditions and increased leaching of phosphorus? Journal of Environmental Management 97, 141-147.

Shaw, R.E., Meyers, W.S., McNeill, A., Tyerman, S.D., 2013. Waterlogging in Australian agricultural landscapes: a review of plant response and crop models. Crop and Pasture Science 64, 549-562.

Smith, J.L., Doran, J.W., 1996. Measurement and use of $\mathrm{pH}$ and electrical conductivity for soil quality analysis. Methods for Assessing Soil Quality. SSSA Special Publication 49. Soil Science Society of America, Madison, WI, pp. 169-185.

Squires, M.M., Lesack, L.F.W., Huebert, D., 2002. The influence of water transparency on the distribution and abundance of macrophytes among lakes of the Mackenzie Delta, Western Canadian Arctic. Freshwater Biology 47, 2123-2135.

Thorne, C., 2014. Geographies of UK Flooding in 2013/4. Geographical Journal 180, 297309.

Yuan, W.L., Cao, C.G., Cheng, J.P., Xie, N.N., 2008. $\mathrm{CH}_{4}$ and $\mathrm{N}_{2} \mathrm{O}$ emissions and their GWPs assessment in intermittent irrigation rice paddy field. Scientia Agricultura Sinica 41, 4294-4300.

Zelles, L., 1999. Fatty acids patterns of phospholipids and lipopolysaccharides in the characterization of microbial communities in soil: a review. Biology and Fertility of Soils 29, 111-129. 
871 Zhang, G.B., Ji, Y., Ma, J., Xu, H., Cai, Z.C., Yagi, K., 2012. Intermittent irrigation changes

872

873

874

875

876

877

878

879

880

881

882

883

884

885

886

887

888

889

890

891

892

893

894

895

896 production, oxidation, and emission of $\mathrm{CH}_{4}$ in paddy fields determined with stable carbon isotope technique. Soil Biology and Biochemistry 52, 108-116.

Zheng, B., Marschner, P., 2017. Previous residue addition rate and $\mathrm{C} / \mathrm{N}$ ratio influence nutrient availability and respiration rate after the second residue addition. Geoderma $285,217-224$.

Zhong-Cheng, L., Qi-Gen, D., Shi-Chao, Y., Fu-Guan, W., Yu-Shu, J., Jing-Dou, C., LuShen, X., Hong-Cheng, Z., Zhong-Yang, H., Ke, X., Hai.Yan, W., 2012. Effects of nitrogen application levels on ammonia volatilization and nitrogen utilization during rice season. Rice Science 19, 125-134.

(1)

(1)

(1)

\section{5}

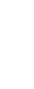

. 


\section{Figure legends}

904 Fig. 1 Time course (mean value) of $\mathrm{pH}$ and EC in soil solution and flood water, and redox 905 potential in soil, as a function of flood treatments. Vertical bars in the upper part represent

906 907 Bonferroni values at $\alpha=0.05$ and the presence of asterisk/s indicate significant differences (*: $P<0.05, * *: P<0.01, * * *: P<0.001)$. T1: soil samples without vegetation, flooded and kept under darkness. T2: soil samples with vegetation, flooded and kept under darkness. T3: vegetation cut from T1 before the flood stage, flooded and under kept under darkness. T4: soil samples with vegetation, flooded and maintained in the light. T5 (control): soil samples with vegetation and maintained in the light. Four replicates per treatment.

Fig. 2 Time course (mean value) of Fe, $\mathrm{P}$ and ${ }^{33} \mathrm{P}$ in soil solution and flood water as a function of flood treatments. Vertical bars in the upper part represent Bonferroni values at $\alpha=0.05$ and the presence of asterisk/s indicate significant differences $(*: P<0.05, * *: P<0.01, * * *: P<$ 0.001). T1: soil samples without vegetation, flooded and kept under darkness. T2: soil samples with vegetation, flooded and kept under darkness. T3: vegetation cut from T1 before the flood stage, flooded and under kept under darkness. T4: soil samples with vegetation, flooded and maintained in the light. T5 (control): soil samples with vegetation and maintained in the light. Four replicates per treatment. 
922 Fig. 3 Time course (mean value) of $\mathrm{NH}_{4}{ }^{+}$and $\mathrm{NO}_{3}{ }^{-}$in soil solution and flood water as a

923 function of flood treatments. Vertical bars in the upper part represent Bonferroni values at $\alpha=$ 9240.05 and the presence of asterisk/s indicate significant differences $(*: P<0.05, * *: P<0.01$,

925

Fig. 4 Time course (mean value) of DON and DOC in soil solution and flood water as a function of flood treatments. Vertical bars in the upper part represent Bonferroni values at $\alpha=$ 0.05 and the presence of asterisk/s indicate significant differences $(*: P<0.05, * *: P<0.01$, ***: $P<0.001)$. T1: soil samples without vegetation, flooded and kept under darkness. T2: soil samples with vegetation, flooded and kept under darkness. T3: vegetation cut from T1 before the flood stage, flooded and under kept under darkness. T4: soil samples with vegetation, flooded and maintained in the light. T5 (control): soil samples with vegetation and maintained in the light. Four replicates per treatment.

Fig. 5 Daily (left) and cumulative (right) fluxes of $\mathrm{CH}_{4}, \mathrm{CO}_{2}$ and $\mathrm{N}_{2} \mathrm{O}$ (mean value) during the soil recovery stage as a function of flood treatments. Different letters mean differences according to Bonferroni multiple comparison test for daily fluxes and Tukey's HSD test for the last determination of cumulative fluxes at a probability level of 0.05 . Vertical bars in the upper part represent Bonferroni and Tukey's HSD values, respectively for daily and cumulative fluxes, at $\alpha=0.05$ and the presence of asterisk/s indicate significant differences (*: $P<0.05, * *: P<0.01, * * *: P<0.001)$. T1: soil samples without vegetation, flooded and kept under darkness. T2: soil samples with vegetation, flooded and kept under darkness. T4: 
950

951

952

953

954

955

956

957

958

959

960

961

962

963

964

965

966

967

soil samples with vegetation, flooded and maintained in the light. T5 (control): soil samples with vegetation and maintained in the light. Four replicates per treatment.

Fig. 6 Total amount of PLFAs from soil samples (a, b), taxonomic groups (c, d) and ratios (e , f) based on PLFAs after flood stage (left) and after soil recovery stage (right) as a function of flood treatments. Different letters mean differences according to Tukey's HSD test at a probability level of 0.05 . T1: soil samples without vegetation, flooded and kept under darkness. T2: soil samples with vegetation, flooded and kept under darkness. T4: soil samples with vegetation, flooded and maintained in the light. T5 (control): soil samples with vegetation and maintained in the light. Four replicates per treatment.

Fig. 7 Principal component analysis for PLFAs (taxonomic groups and ratios based on PLFAs), GHG emissions, redox potential in soil, $\mathrm{NH}_{4}{ }^{+}$and $\mathrm{NO}_{3}{ }^{-}$in soil solution after flood stage (a and c) and after soil recovery stage (b and d) as a function of flood treatments. The separation between treatments or biplot is shown at the left and the corresponding loading of each variable included in the PCA at right. T1: soil samples without vegetation, flooded and kept under darkness. T2: soil samples with vegetation, flooded and kept under darkness. T3: vegetation cut from T1 before the flood stage, flooded and under kept under darkness. T4: soil samples with vegetation, flooded and maintained in the light. T5 (control): soil samples with vegetation and maintained in the light. Four replicates per treatment. 


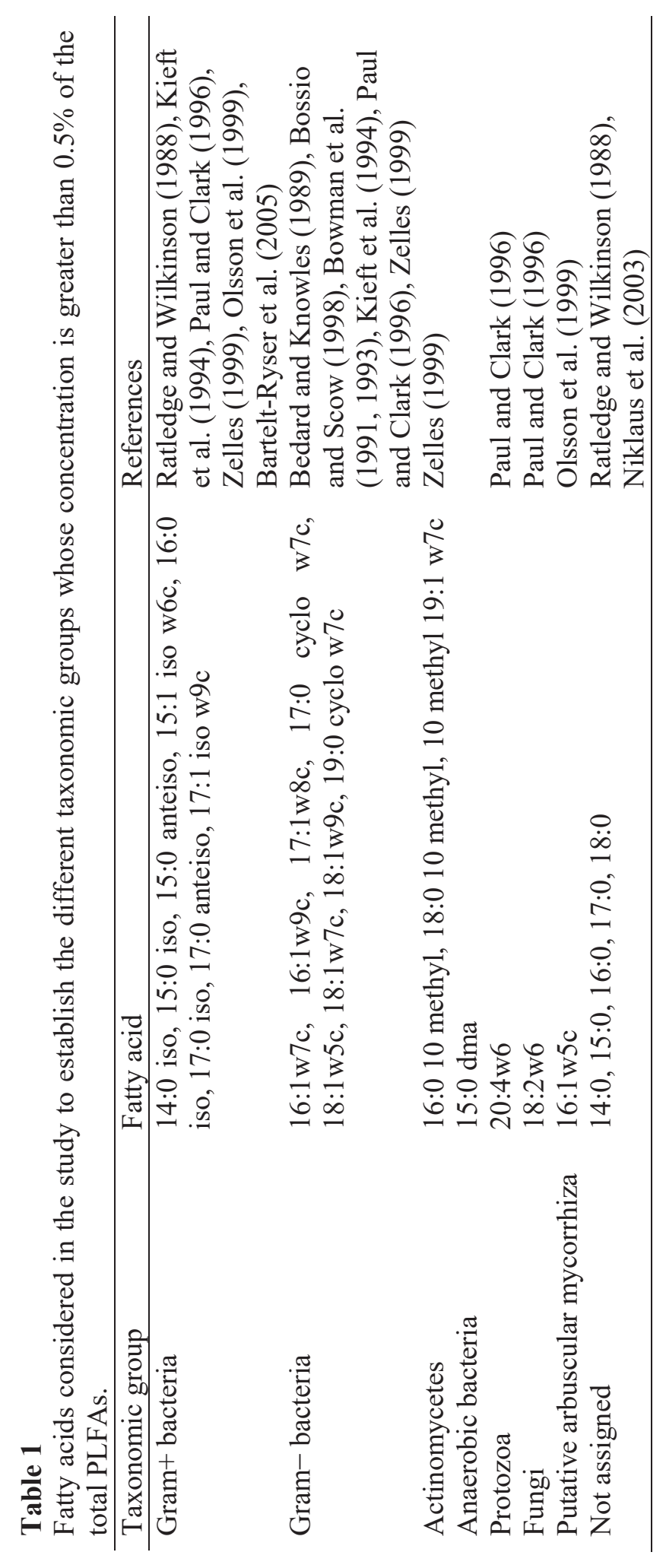


Table 2

Grass above-ground dry weight and number of earthworms at the end of the soil recovery stage as a function of the flooding treatment. $P$ is the ANOVA $P$-value. Different letters indicate differences between treatments according to Tukey's HSD post hoc test $(P<0.05)$. Four replicates per treatment.

\begin{tabular}{lcl}
\hline Treatment & $\begin{array}{c}\text { Grass production } \\
\left(\mathrm{g} \text { mesocosm }^{-1}\right)\end{array}$ & $\begin{array}{l}\text { Earthworms } \\
\left(\text { mesocosm }^{-1}\right)\end{array}$ \\
\hline $\mathrm{T}_{1}$ : Flood + dark (no veg) & $0.5 \pm 0.1 \mathrm{c}$ & $0.0 \pm 0.0 \mathrm{~b}$ \\
$\mathrm{~T}_{2}$ : Flood + dark & $0.6 \pm 0.1 \mathrm{c}$ & $0.0 \pm 0.0 \mathrm{~b}$ \\
$\mathrm{~T}_{4}$ : Flood + light & $10.9 \pm 2.2 \mathrm{~b}$ & $0.0 \pm 0.0 \mathrm{~b}$ \\
$\mathrm{~T}_{5}$ : Control + light & $28.0 \pm 1.8 \mathrm{a}$ & $4.8 \pm 0.8 \mathrm{a}$ \\
$P$ & $<0.001$ & $<0.001$ \\
\hline
\end{tabular}

$\mathrm{T}_{1}$ : Flood + dark (no veg.): soil samples without vegetation, flooded and maintained in the dark.

$\mathrm{T}_{2}$ : Flood + dark: soil samples with vegetation, flooded and maintained in the dark.

$\mathrm{T}_{4}$ : Flood + light: soil samples with vegetation, flooded and maintained in the light.

$\mathrm{T}_{5}$ : Control + light: soil samples with vegetation, no flooding and maintained in the light. 


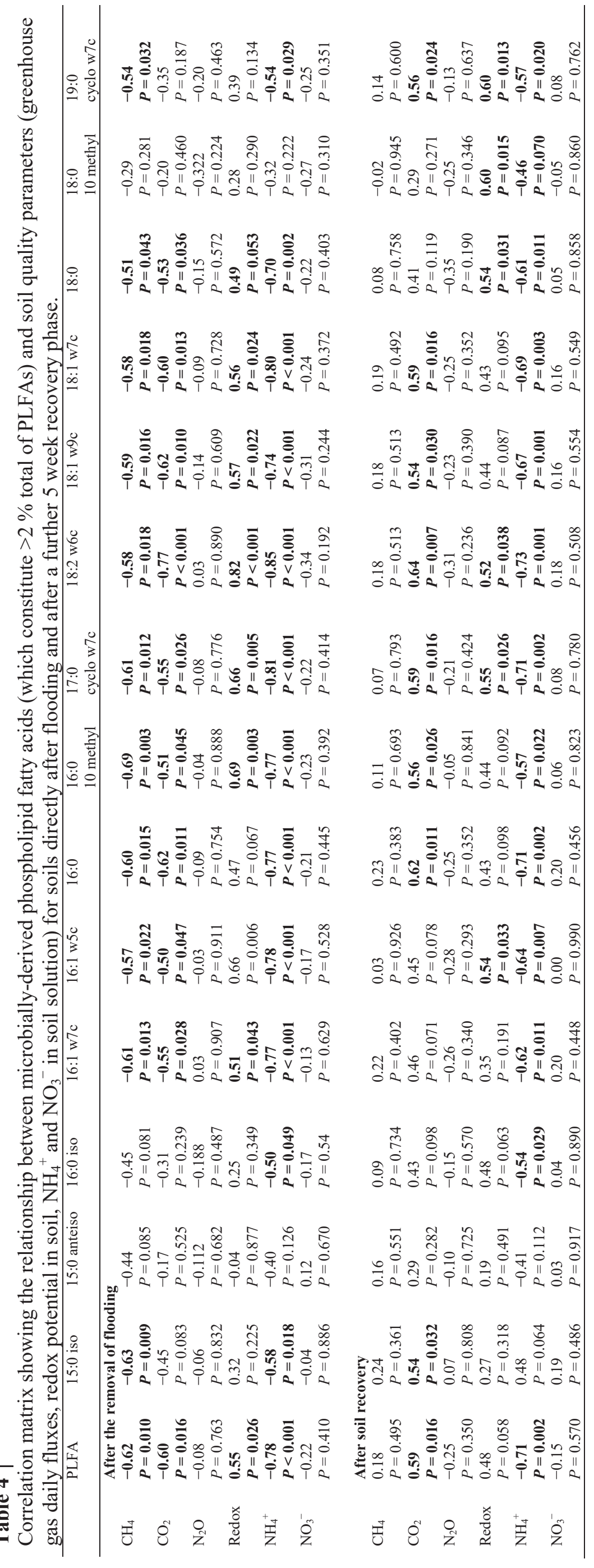


Table 3

Correlation matrix showing the relationship between daily greenhouse gas (GHG) emissions $\left(\mathrm{CO}_{2}, \mathrm{~N}_{2} \mathrm{O}\right.$ and $\left.\mathrm{CH}_{4}\right)$ and key soil quality parameters (redox potential, $\mathrm{NH}_{4}^{+}$ and $\mathrm{NO}_{3}{ }^{-}$) during soil recovery. Significant relationships are shown in bold.

\begin{tabular}{llllll}
\hline & $\mathrm{CH}_{4}$ & $\mathrm{CO}_{2}$ & $\mathrm{~N}_{2} \mathrm{O}$ & Redox & $\mathrm{NH}_{4}^{+}$ \\
\hline $\mathrm{CO}_{2}$ & -0.013 & & & & \\
& $P=0.919$ & & & & \\
$\mathrm{~N}_{2} \mathrm{O}$ & -0.17 & 0.03 & & & \\
& $P=0.181$ & $P=0.792$ & & & \\
Redox & $\mathbf{- 0 . 5 6}$ & 0.06 & 0.14 & & \\
& $\boldsymbol{P}<\mathbf{0 . 0 0 1}$ & $P=0.637$ & $P=0.264$ & & \\
$\mathrm{NH}_{4}{ }^{+}$ & $\mathbf{0 . 6 0}$ & 0.01 & 0.188 & $\mathbf{0 . 5 8}$ & \\
& $\boldsymbol{P}<\mathbf{0 . 0 0 1}$ & $P=0.920$ & $P=0.137$ & $\boldsymbol{P}<\mathbf{0 . 0 0 1}$ & \\
$\mathrm{NO}_{3}{ }^{-}$ & -0.12 & -0.03 & 0.11 & -0.05 & -0.06 \\
& $P=0.353$ & $P=0.802$ & $P=0.396$ & $P=0.708$ & $P=0.633$ \\
\hline
\end{tabular}


Soil solution

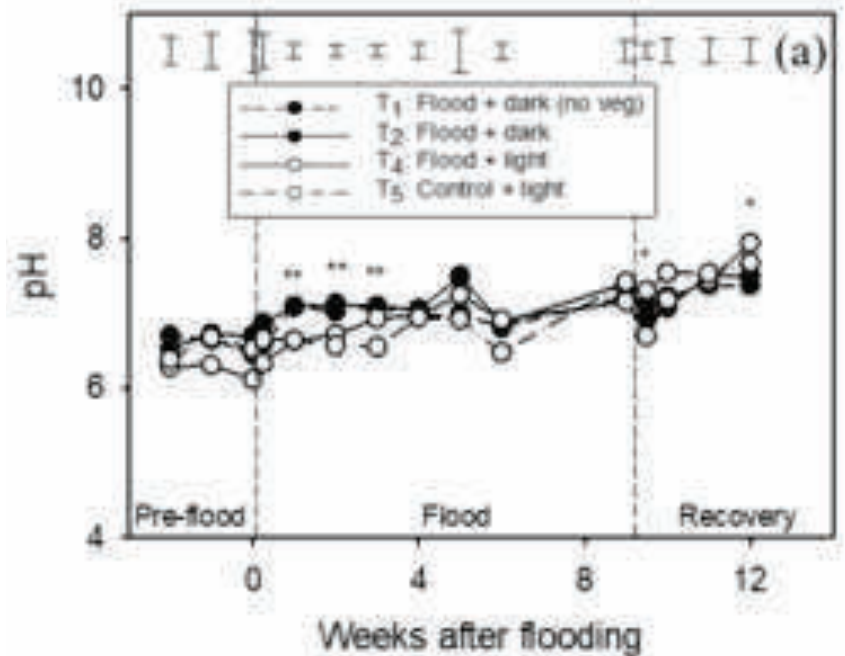

Soil solution

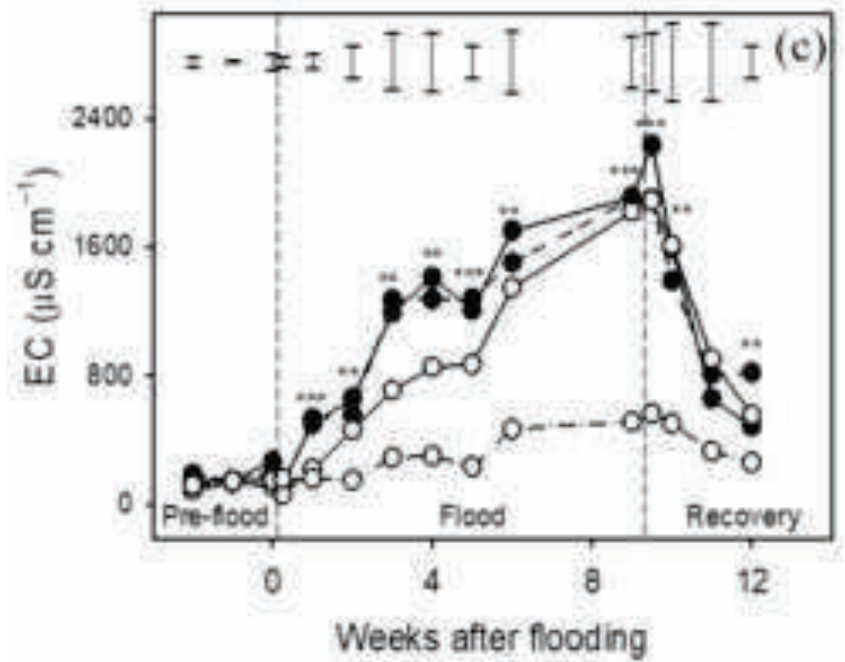

Soll

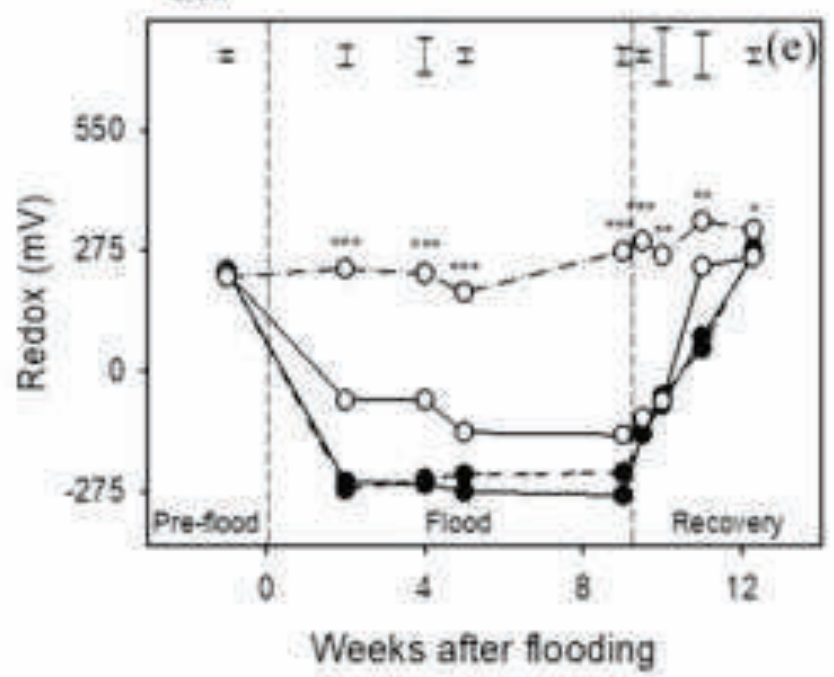

Figure 1

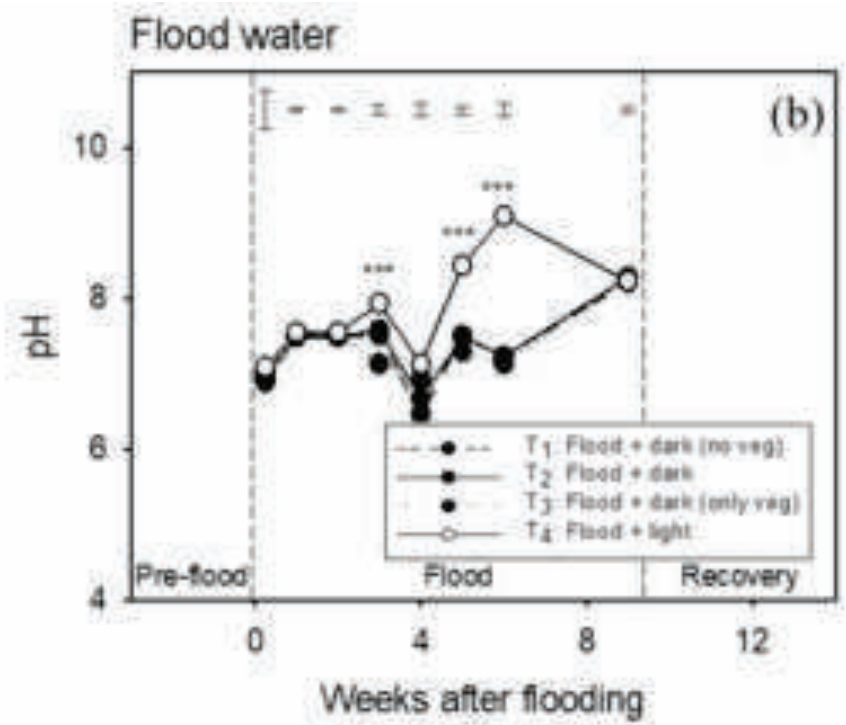

Flood water

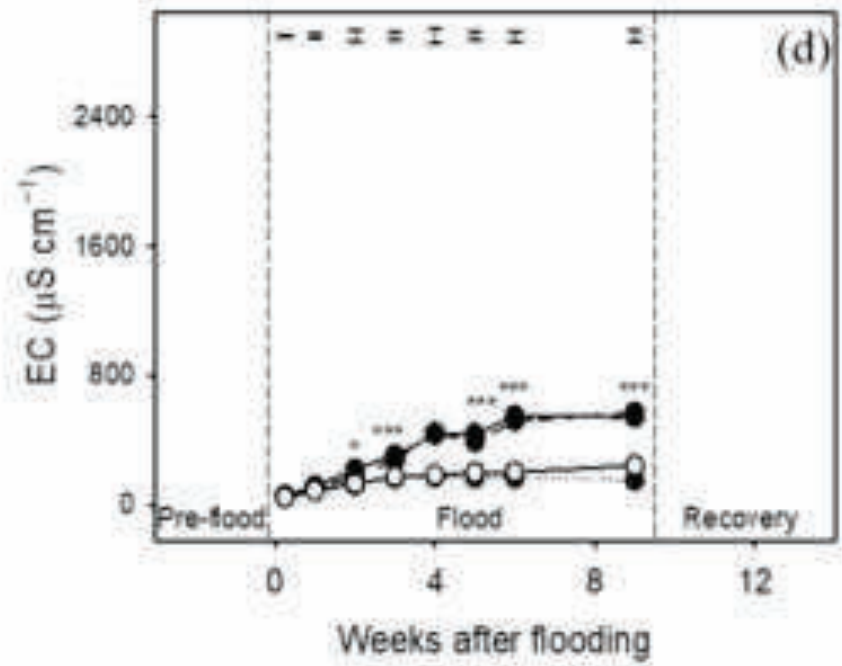


Soil solution

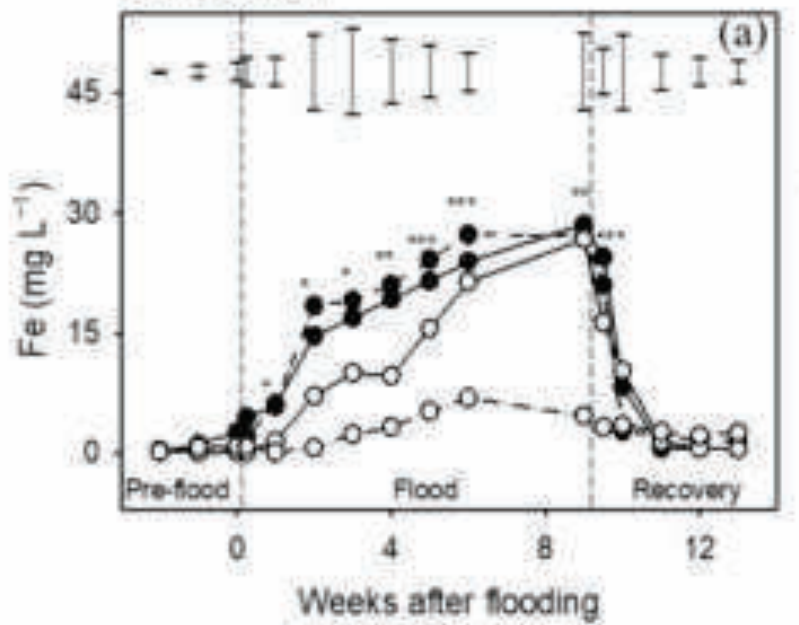

Soll solution

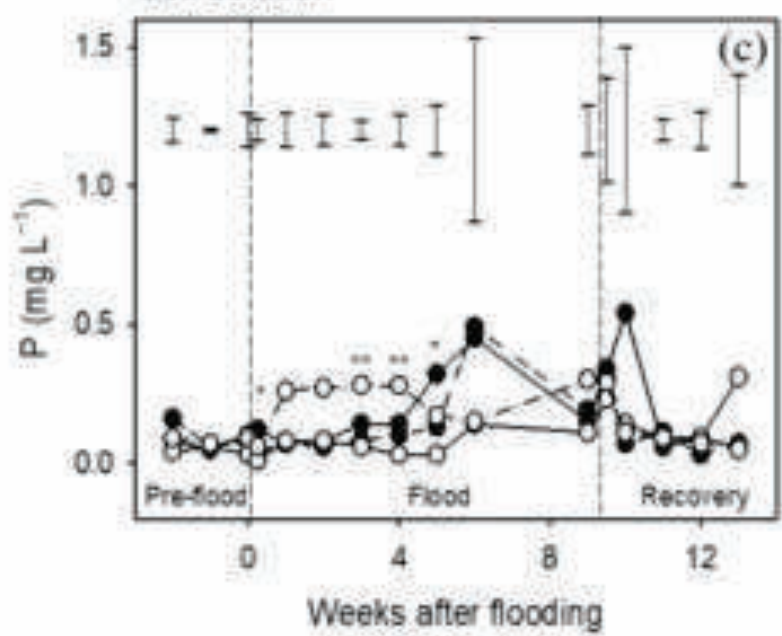

Soil solution
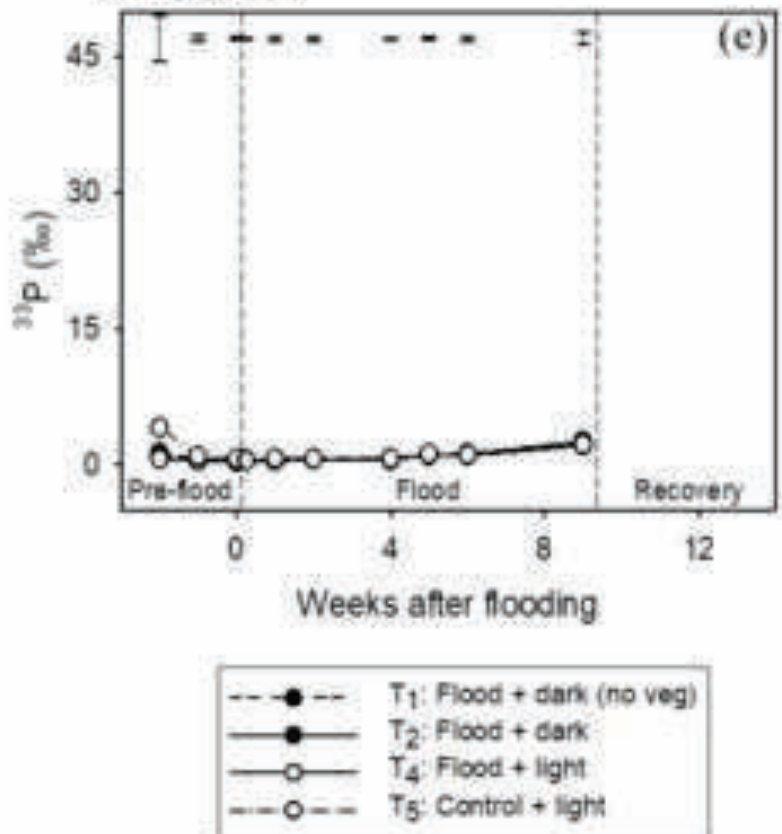

\section{Flood water}

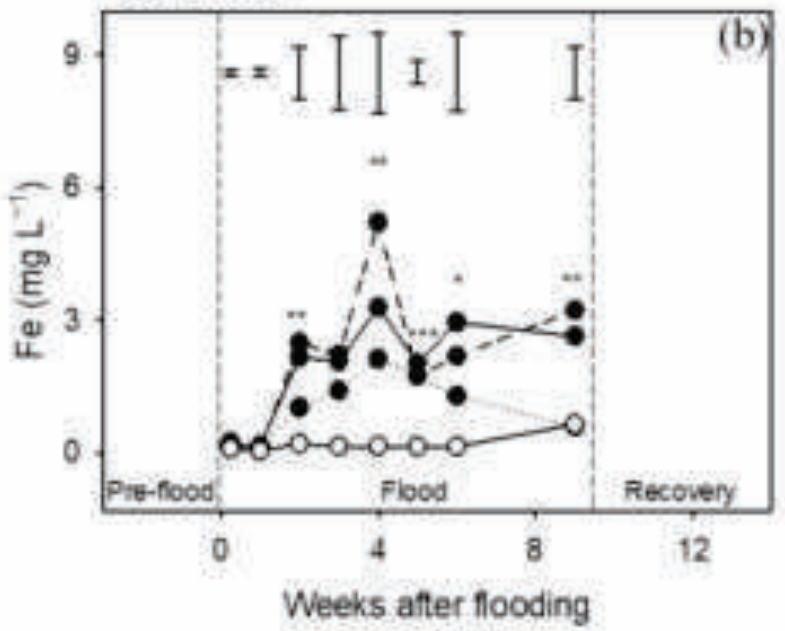

Flood water

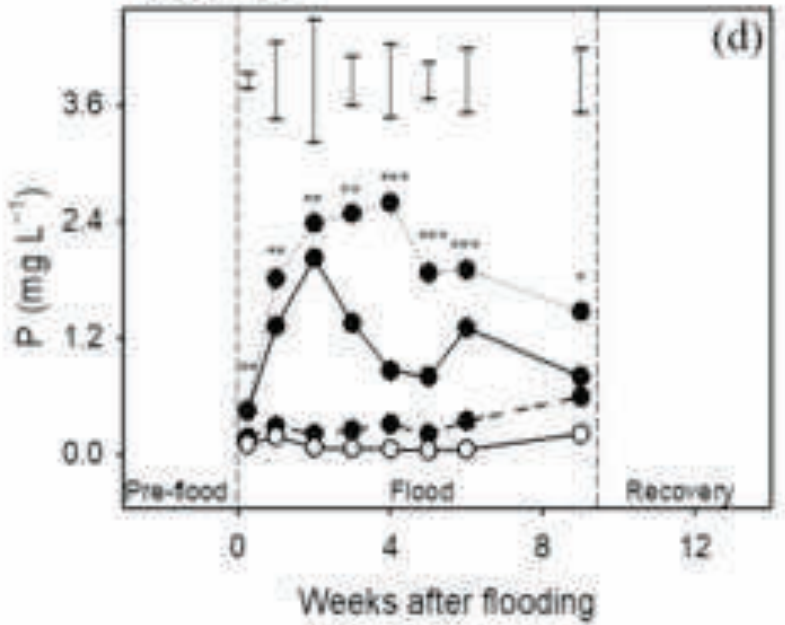

Flood water
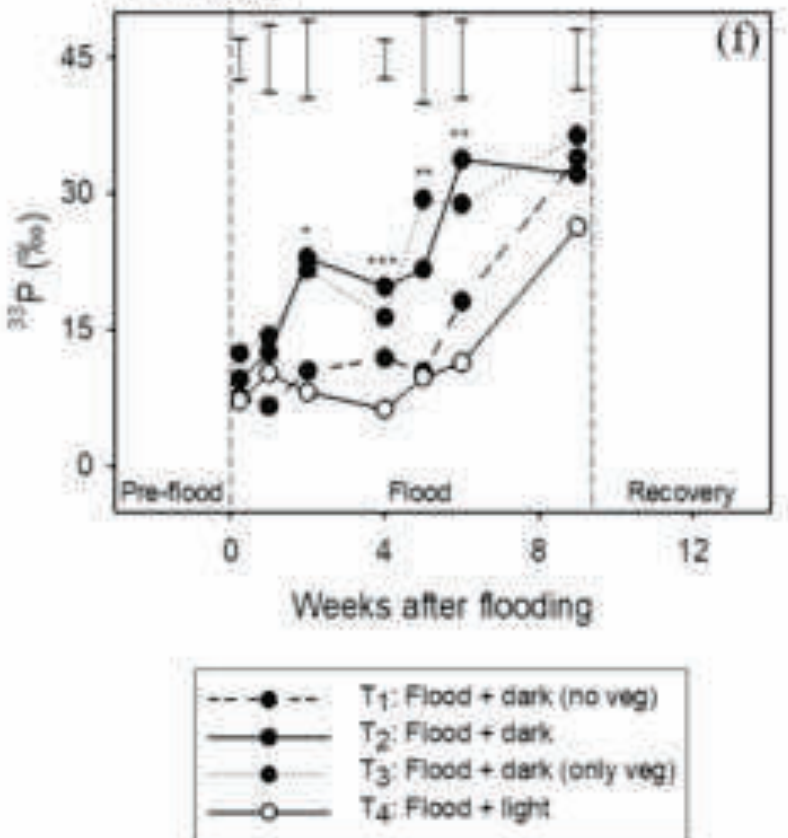
Figure 3

Click here to download high resolution image

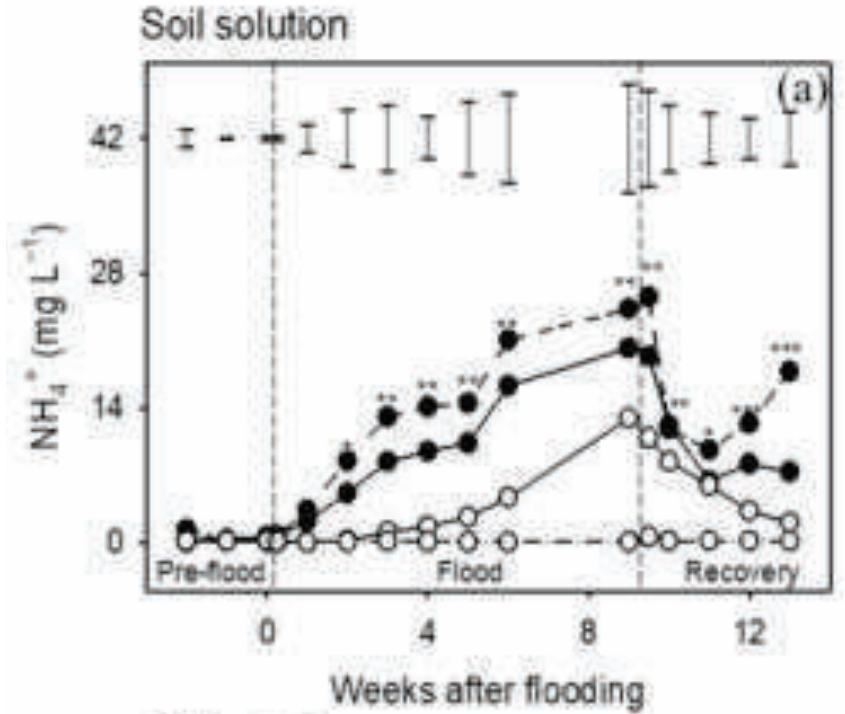

Soil solution
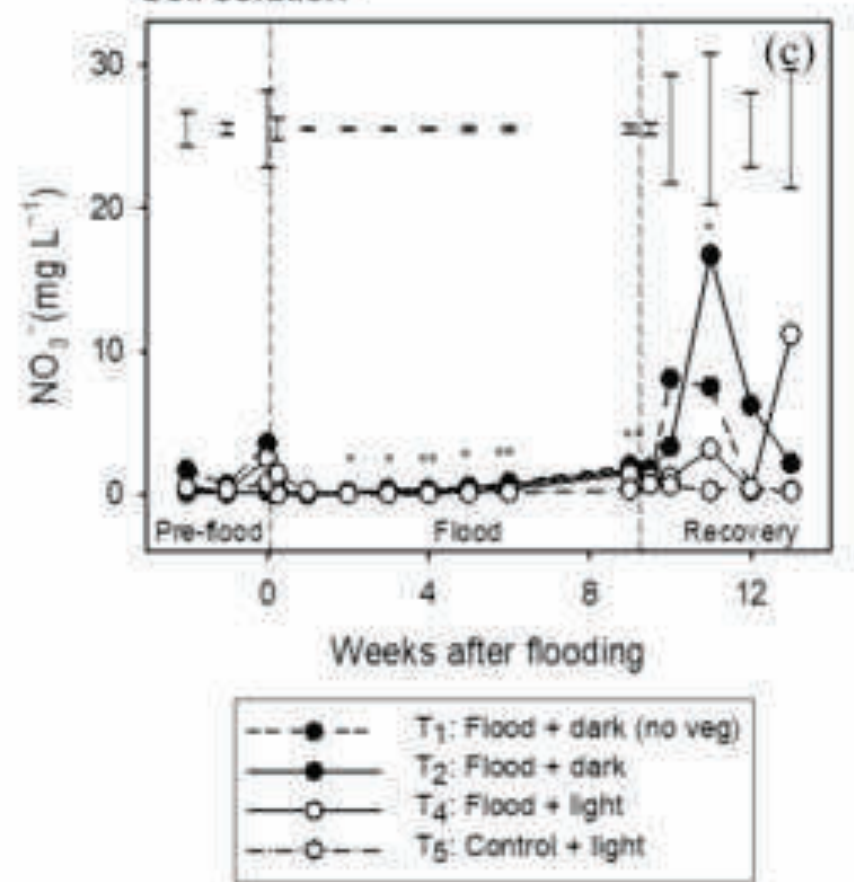

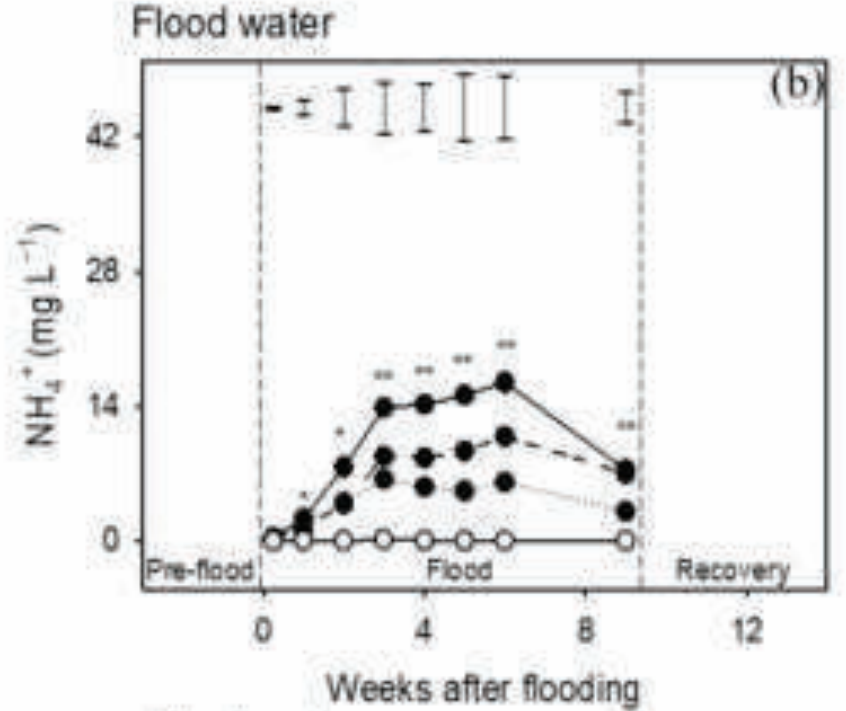

Flood water

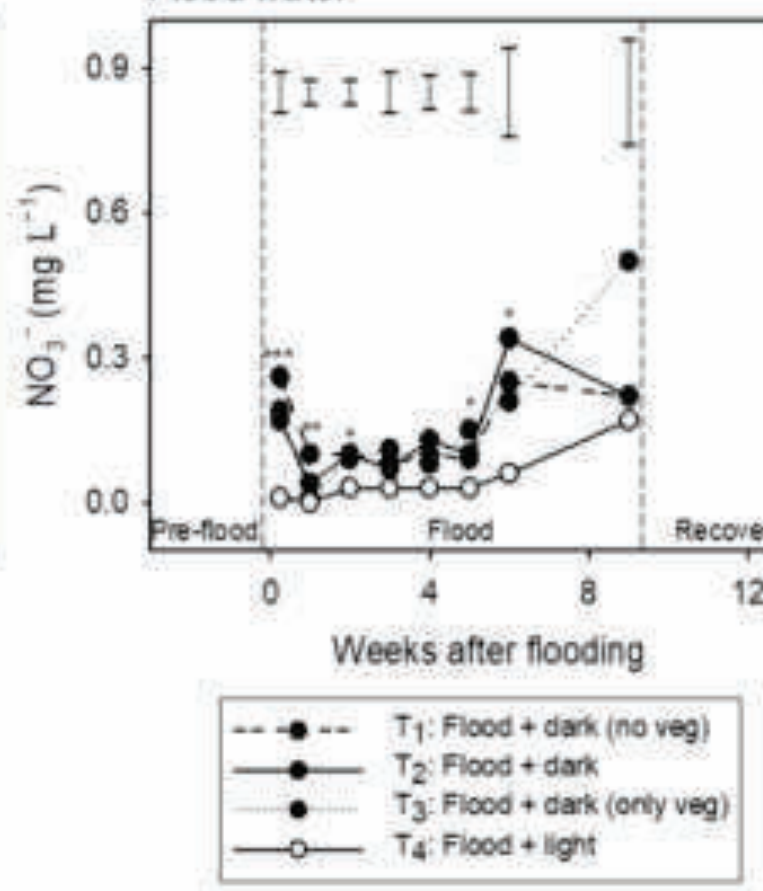

\section{Figure 3}


Figure 4

Click here to download high resolution image

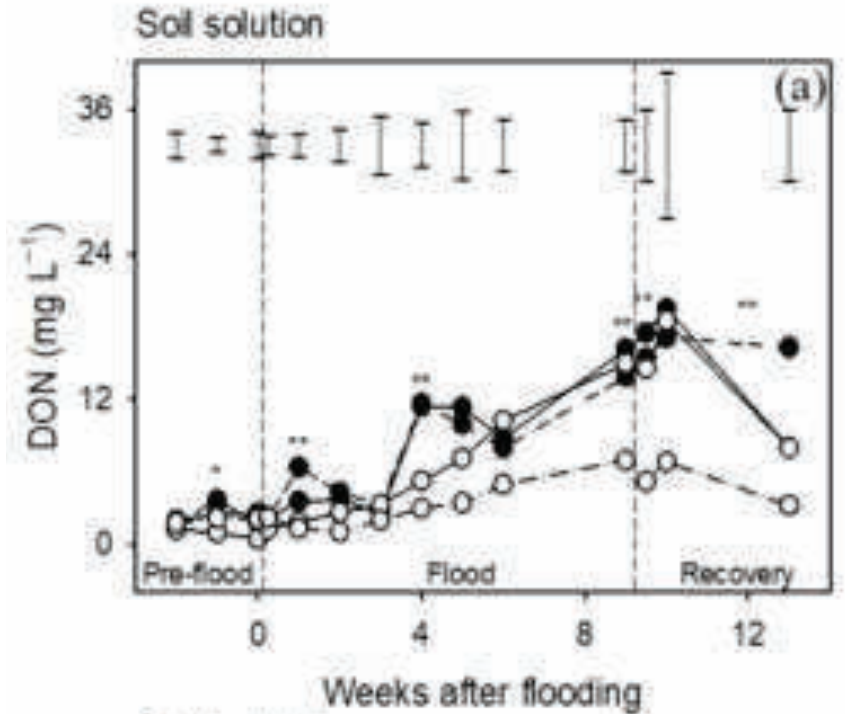

Soil solution

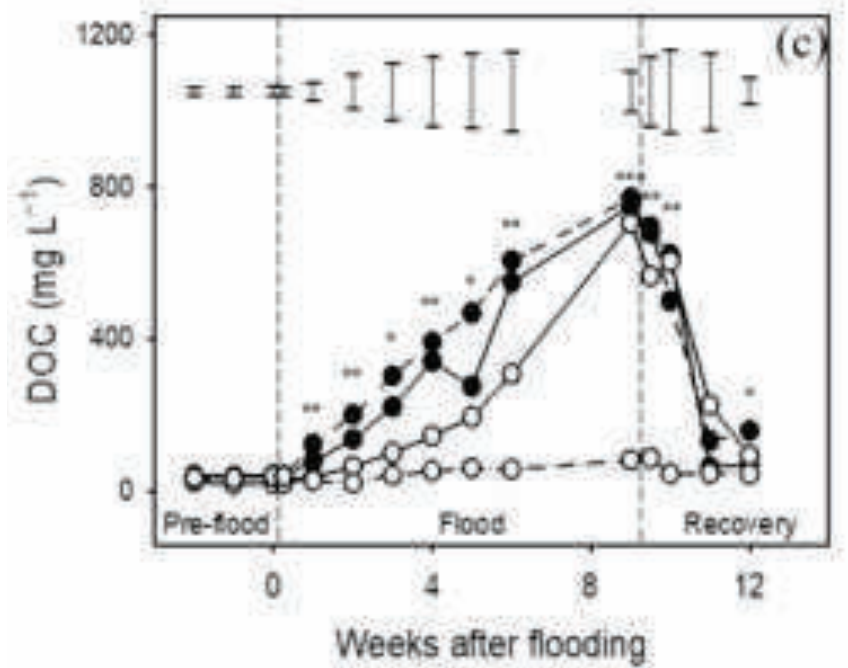

$\longrightarrow T_{1}$ Flood + dark (no veg)
$\longrightarrow-T_{2} ;$ Flood + dark
$\longrightarrow-0-T_{4}:$ Flood + light
$-0-T_{5}$ : Controt + light

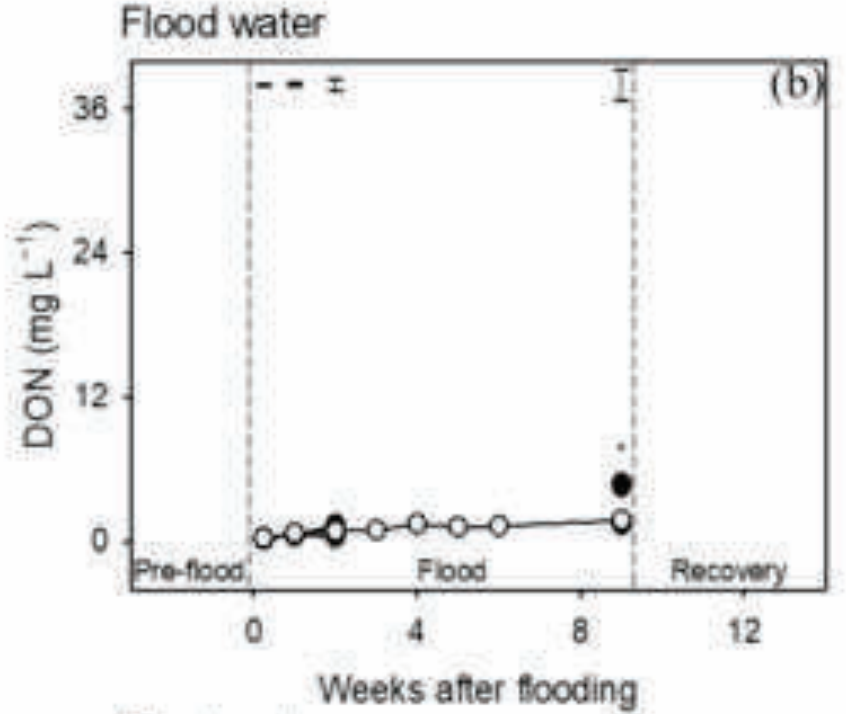

Flood water

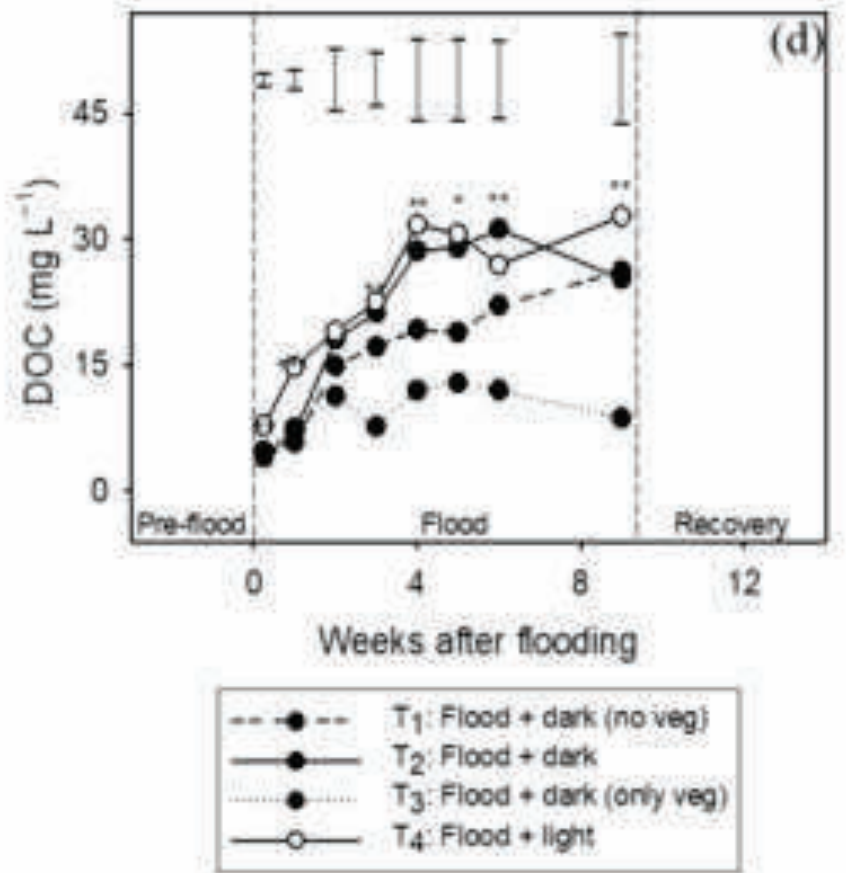

Figure 4 

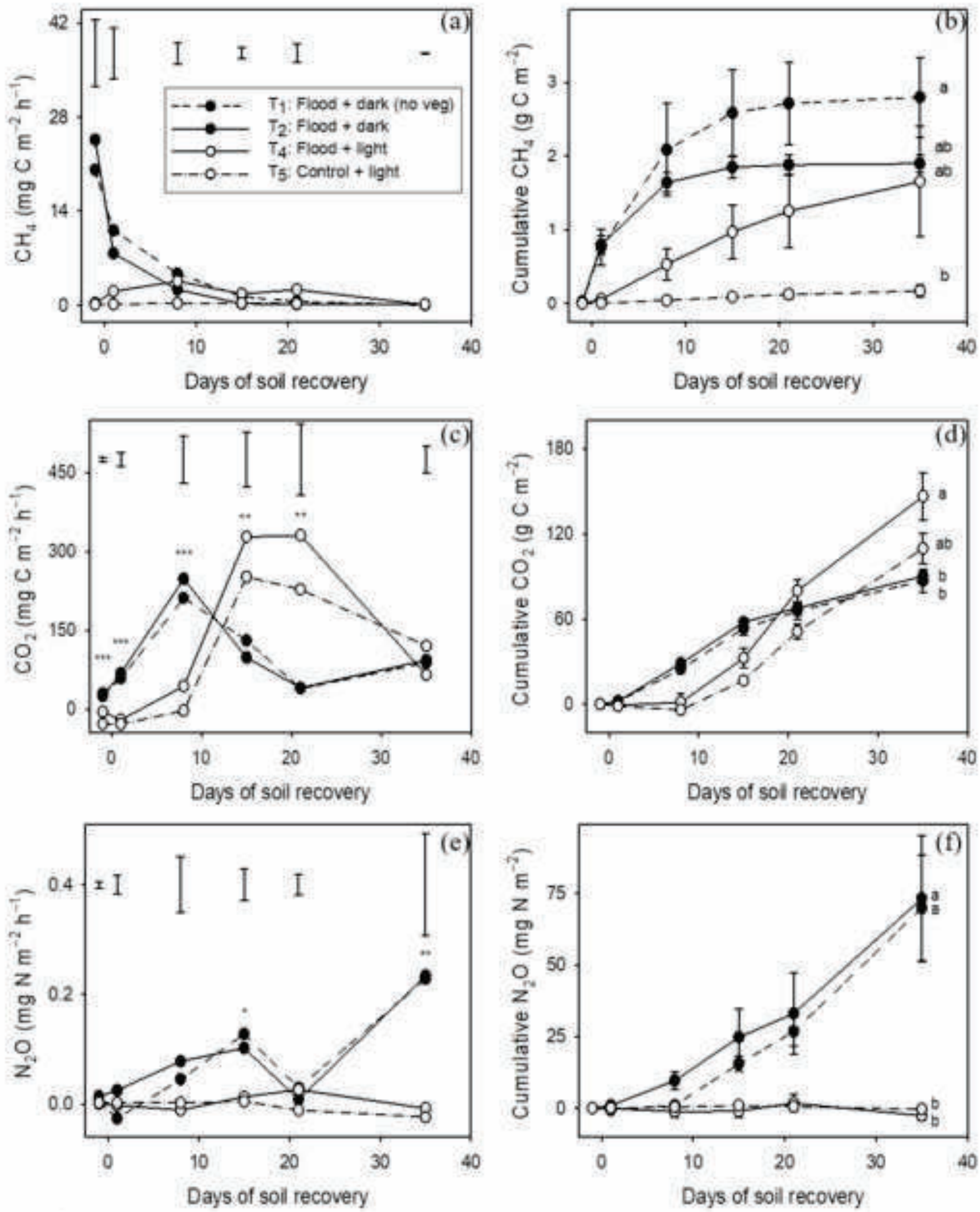

Figure 5 
Click here to download high resolution image
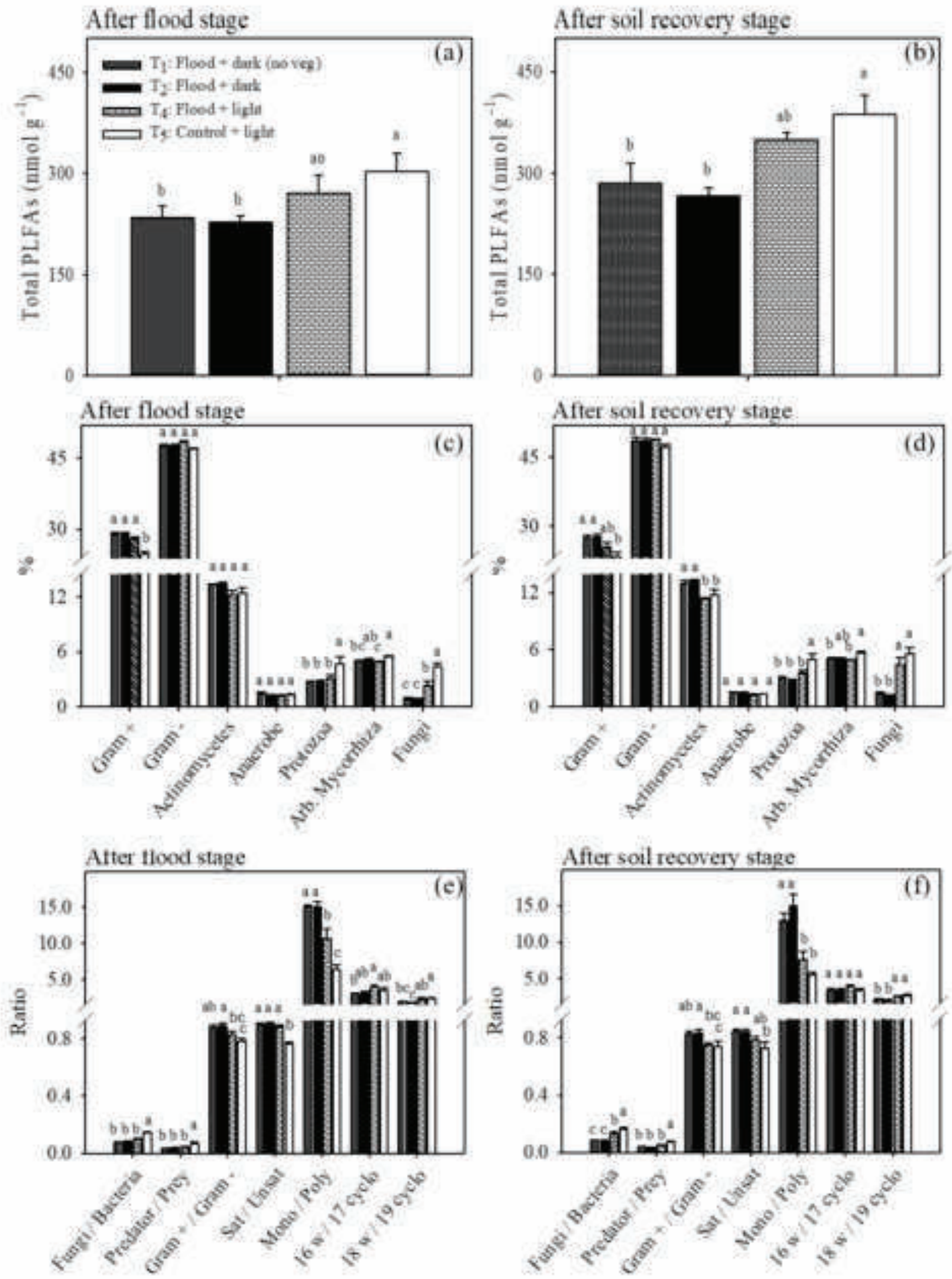

Figure 6 
(a) Taxonouic groups after flood stage

Variables

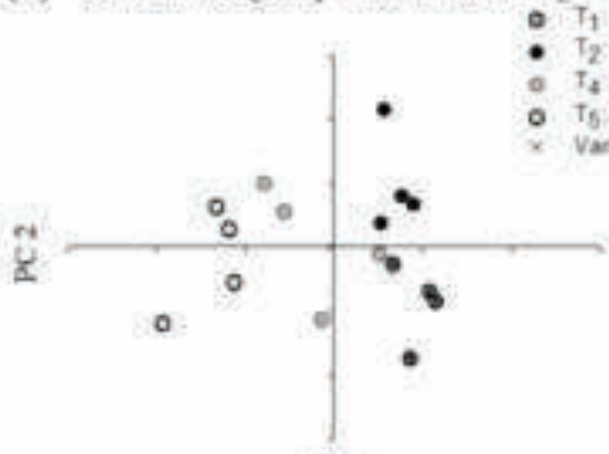

$T_{2}$ hlood $+\operatorname{dan}$

$T_{4}$ Flead + lighit

if Contivol * ight

Vanains

PCI

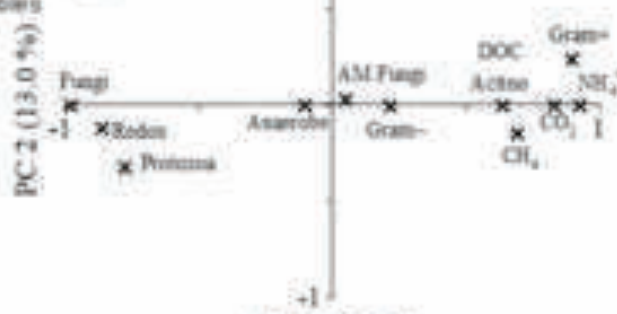

$\mathrm{PCl}(47,346)$

(b) Taxonouic groups after soil recovery

Variables
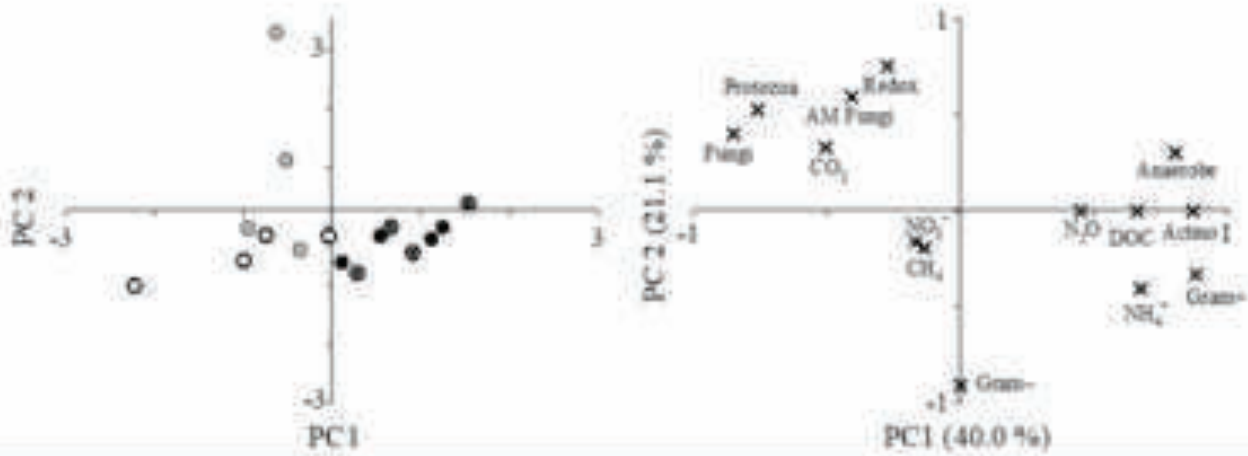

(c) Ratios after flood stage

Variables

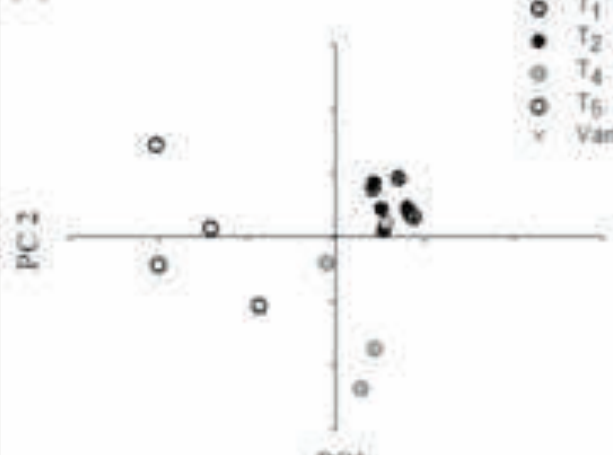

T4. hioed $+\tan (\operatorname{tes} v 00)$

$1_{4}$. Plood - ing

T5. Centrol + igin

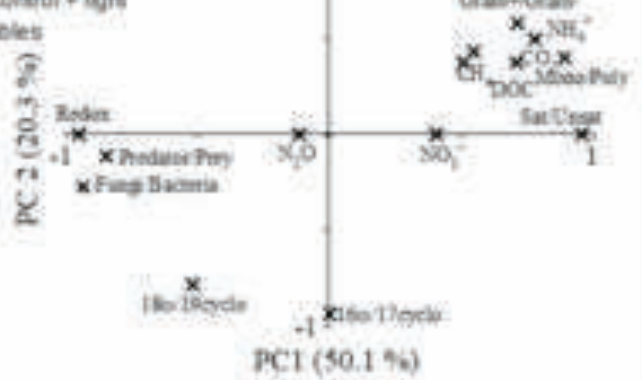

(d) Ratios affer soil recovery

Viriables

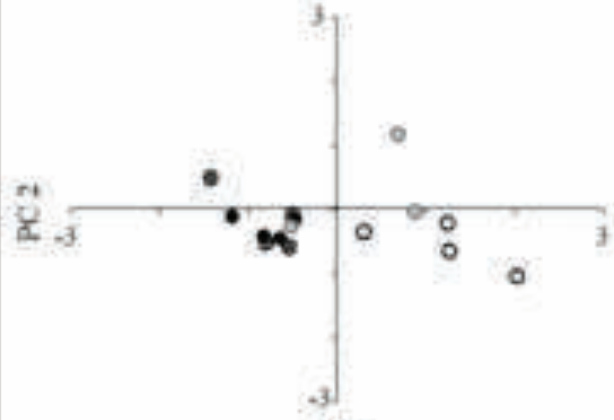

$\mathrm{PC} 1$

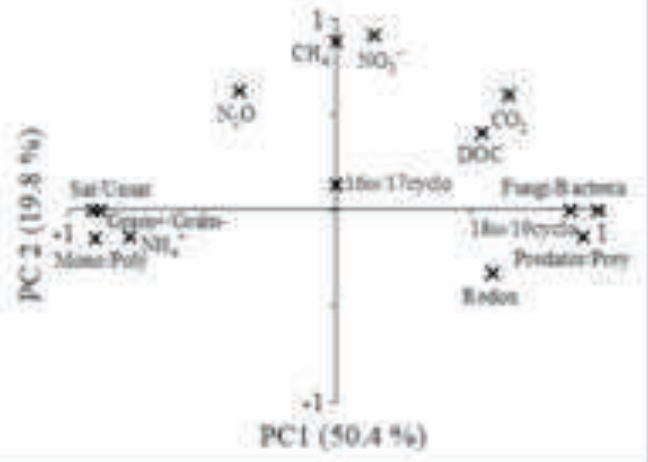

$\mathrm{PCl}(50,4 \% 6)$

Figure 7 
Click here to download Supplementary Material for online publication only: Supp Info DLJ.docx 